\title{
Volatile organic compounds and ozone air pollution in an oil production region in northern China
}

\author{
Tianshu Chen ${ }^{1}$, Likun Xue ${ }^{1,2}$, Penggang Zheng ${ }^{1}$, Yingnan Zhang ${ }^{1}$, Yuhong Liu ${ }^{1}$, Jingjing Sun ${ }^{1}$, Guangxuan Han ${ }^{3}$, \\ Hongyong $\mathrm{Li}^{1}$, Xin Zhang ${ }^{1,4}$, Yunfeng $\mathrm{Li}^{1,4}$, Hong $\mathrm{Li}^{4}$, Can Dong ${ }^{1}$, Fei Xu ${ }^{1,2}$, Qingzhu Zhang ${ }^{1}$, and Wenxing Wang ${ }^{1}$ \\ ${ }^{1}$ Environment Research Institute, Shandong University, Jinan, Shandong, China \\ ${ }^{2}$ Shenzhen Research Institute of Shandong University, Shenzhen, Guangdong, China \\ ${ }^{3}$ Key Laboratory of Coastal Environmental Process and Ecology Remediation, Yantai Institute of Coastal Zone Research, \\ Chinese Academy of Sciences, Yantai, Shandong, China \\ ${ }^{4}$ Chinese Research Academy of Environmental Sciences, Beijing, China
}

Correspondence: Likun Xue (xuelikun@sdu.edu.cn)

Received: 13 August 2019 - Discussion started: 5 December 2019

Revised: 25 March 2020 - Accepted: 6 May 2020 - Published: 15 June 2020

\begin{abstract}
Oil and natural gas (O\&NG) exploration presents a significant source of atmospheric volatile organic compounds (VOCs), which are central players of tropospheric chemistry and contribute to formations of ozone $\left(\mathrm{O}_{3}\right)$ and secondary organic aerosols. The impacts of O\&NG extraction on regional air quality have been investigated in recent years in North America, but have long been overlooked in China. To assess the impacts of O\&NG exploration on tropospheric $\mathrm{O}_{3}$ and regional air quality in China, intensive field observations were conducted during February-March and June-July 2017 in the Yellow River delta, an oil extraction region in northern China. Very high concentrations of ambient VOCs were observed at a rural site, with the highest alkane mixing ratios reaching $2498 \mathrm{ppbv}$. High- $\mathrm{O}_{3}$ episodes were not encountered during wintertime but were frequently observed in summer. The emission profiles of VOCs from the oil fields were directly measured for the first time in China. The chemical budgets of $\mathrm{RO}_{x}$ radicals and $\mathrm{O}_{3}$ were dissected with a detailed chemical box model constrained by in situ observations. The highly abundant VOCs facilitated strong atmospheric oxidation capacity and $\mathrm{O}_{3}$ formation in the region. Oxygenated VOCs (OVOCs) played an essential role in the $\mathrm{RO}_{x}$ primary production, $\mathrm{OH}$ loss, and radical recycling. Photolysis of OVOCs, $\mathrm{O}_{3}$, and $\mathrm{HONO}$ as well as ozonolysis reactions of unsaturated VOCs were major primary sources of $\mathrm{RO}_{x} . \mathrm{NO}_{x}$ was the limiting factor of radical recycling and $\mathrm{O}_{3}$ formation. This study underlines the important impacts of
\end{abstract}

O\&NG extraction on atmospheric chemistry and regional air quality in China.

\section{Introduction}

Oil and natural gas (O\&NG) compose the most significant fraction of global energy consumption and play an essential role in the industry, economy, and social development. By the end of 2017, O\&NG consumption accounted for approximately $58 \%$ of global primary energy consumption (British Petroleum Company plc., 2018). In recent years, with the breakthroughs in exploration and extraction technologies for tight oil and shale gas such as horizontal drilling and hydraulic fracturing (EIA, 2014), the unconventional O\&NG production has experienced explosive growth in the United States, resulting in an upward trend of O\&NG production since the 1980s (EIA, 2018). Increases in O\&NG production are also projected in other countries with abundant reservoirs of shale oil and gas in the near future (EIA, 2014). O\&NG production emits a large amount of air pollutants to the atmosphere, causing different levels of air pollution problems in the O\&NG extraction region and its surrounding areas (Schnell et al., 2009; Edwards et al., 2013). The growth in O\&NG production has indeed raised increasing concerns about the deteriorated air quality, public health, and climate in North America (Alvarez et al., 2012; McKenzie et 
al., 2012; Adgate et al., 2014; Colborn et al., 2014; Field et al., 2014).

Potential air pollutant emission sources during O\&NG production include deliberate venting and flaring, fugitive emissions, diesel engines for power supply, and leakage from infrastructure and transport (Adgate et al., 2014). Such activities have been shown to result in the increase in volatile organic compounds (VOCs) and nitrogen oxides $\left(\mathrm{NO}_{x}\right)$ in the ambient air (Allen et al., 2013; Helmig et al., 2014; Warneke et al., 2014). Photochemical oxidation of VOCs in the presence of $\mathrm{NO}_{x}$ produces ozone $\left(\mathrm{O}_{3}\right)$, a secondary pollutant with adverse effects on human health, vegetation, materials, and climate (National Research Council, 1992). Several field campaigns have observed unusually high levels of wintertime $\mathrm{O}_{3}$ in oil and gas field basins in the US, including the Uintah Basin (Edwards et al., 2013, 2014; Lee et al., 2014) and Upper Green River basin (Schnell et al., 2009; Carter and Seinfeld, 2012). Such high wintertime $\mathrm{O}_{3}$ episodes occur under the combined action of specific meteorological conditions and chemical processes. The favorable meteorological conditions include a shallow boundary layer, calm winds, and increased photolysis flux induced by the snow deposition (Schnell et al., 2009; Carter and Seinfeld, 2012; Ahmadov et al., 2015). In terms of atmospheric chemistry processes, the accumulated high concentrations of VOCs lead to a significant increase in $\mathrm{O}_{3}$ production efficiency, and radicals generated by photolysis of oxygenated VOCs (OVOCs) also play an important role (Edwards et al., 2013, 2014). In addition, the O\&NG production also affects $\mathrm{O}_{3}$ formation and air quality during other seasons, especially in summer. Rodriguez et al. (2009) used a regional chemical transport model (CAMx) to assess the impacts of O\&NG operation on $\mathrm{O}_{3}$ pollution in the western US, and they found enhancement in the maximum daily $8 \mathrm{~h}$ average $\mathrm{O}_{3}\left(\mathrm{MDA} 8 \mathrm{O}_{3}\right.$ ) by considering $\mathrm{O} \& \mathrm{NG}$ emissions can reach up to $9.6 \mathrm{ppbv}$ in southwestern Colorado and northwestern New Mexico. Using the same model, Kemball-Cook et al. (2010) indicated that emissions from Haynesville Shale can explain up to $5 \mathrm{ppbv}$ of MDA8 $\mathrm{O}_{3}$ enhancement within northeast Texas and northwest Louisiana. Other works also found that the O\&NG extraction activities pose important effects on regional $\mathrm{O}_{3} \mathrm{lev}$ els in summertime (Olaguer, 2012; Rutter et al., 2015; Vinciguerra et al., 2015; McDuffie et al., 2016).

The O\&NG exploration activities are very active in China, with crude oil and natural gas production both ranking sixth in the world (EIA, 2017; Statista, 2018). China is also rich in shale resources, with the reserves of shale gas and shale oil ranking first and third in the world, respectively (EIA, 2014). It is expected that China's future O\&NG exploration will further increase and may have increasingly important effects on atmospheric and environmental issues. Currently, $\mathrm{O}_{3}$ pollution has become a major air quality concern in China, with monitored $\mathrm{O}_{3}$ concentrations exceeding the national ambient air quality standard frequently in metropolitan areas nationwide (L. K. Xue et al., 2014; Wang et al., 2017). Available long-term observations also demonstrated significant upward trends in surface $\mathrm{O}_{3}$ levels in the last 2 decades over China (Ding et al., 2008; Wang et al., 2009; Xu et al., 2008, 2018; L. Xue et al., 2014; Sun et al., 2016; Ma et al., 2016). A large number of studies have been dedicated to understanding the formation mechanisms of $\mathrm{O}_{3}$ pollution and identified the major sources of $\mathrm{O}_{3}$ precursors (particularly VOCs) in China (e.g., Zhang et al., 2008; Yuan et al., 2012; Dang et al., 2015; Shao et al., 2016; Zhao et al., 2016; Wang et al., 2017). However, O\&NG extraction has long been overlooked as an important source of VOCs, compared to other anthropogenic activities such as industry, power plants, transportation, biomass burning, etc. To the best of our knowledge, to date there is no report that has assessed the impacts of O\&NG exploration on VOCs and $\mathrm{O}_{3}$ pollution in China.

To fill this gap, two intensive measurement campaigns were conducted at a rural site surrounded by open oil fields in the Yellow River delta (YelRD) region, an important oil extraction area in China, during February-March and JuneJuly of 2017. A large suite of parameters including $\mathrm{O}_{3}, \mathrm{CO}$, $\mathrm{NO}, \mathrm{NO}_{2}, \mathrm{NO}_{y}, \mathrm{SO}_{2}, \mathrm{HONO}, \mathrm{C}_{1}-\mathrm{C}_{10}$ hydrocarbons, $\mathrm{C}_{1}-\mathrm{C}_{8}$ carbonyls, aerosol properties, and meteorological parameters were measured in situ. Air samples were also collected from oil wells to characterize the source profiles of VOCs in the oil field. A detailed chemical box model was then constrained with the abovementioned in situ observations to dissect the chemistry of $\mathrm{O}_{3}$ formation, atmospheric oxidation capacity, and radical budgets. Overall, this study provides some new insights into the emission characteristics of VOCs from oil fields and their effects on atmospheric oxidation processes and regional $\mathrm{O}_{3}$ pollution in China.

\section{Materials and methods}

\subsection{Site description}

We target the YelRD region for assessing the impacts of oil field emissions on VOCs and $\mathrm{O}_{3}$ pollution. The YelRD is located to the south of Bohai Sea and in the northern part of Shandong Province. It includes Dongying, Binzhou, and parts of Weifang, Dezhou, Zibo, and Yantai cities, with a total area of $26500 \mathrm{~km}^{2}$ and a population of 9.85 million (Fig. 1). It is abundant in natural resources and hosts the third largest oil field in China (i.e., Shengli oil field). Active O\&NG exploration has made it one of China's largest petrochemical industry bases. In addition, the YelRD estuary is a typical estuarine wetland ecosystem and is rich in ecological resources. Furthermore, it is located at the junction of the Beijing-Tianjin-Hebei region and Shandong Peninsula, the most polluted regions in north China, with distances of approximately 300,200 , and $190 \mathrm{~km}$ away from Beijing, Tianjin, and Jinan, respectively. Therefore, it may also suffer from regional transport of aged continental air masses from these metropolitan areas under the influence of winter monsoons. 


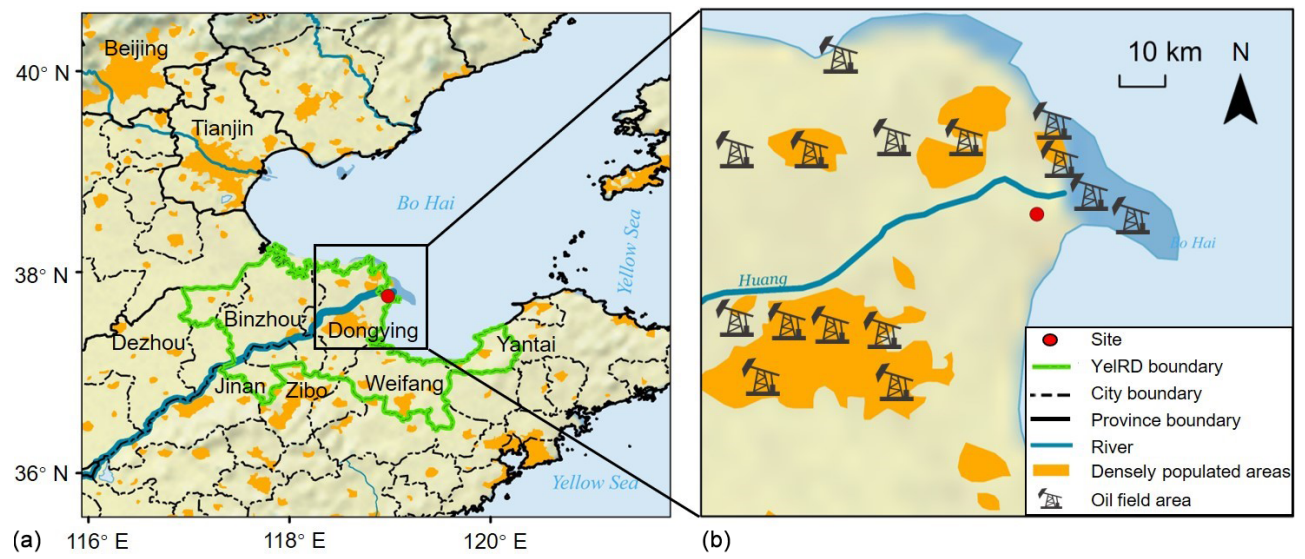

Figure 1. Map showing the location of the Yellow River delta. Panel (b) shows the surroundings of the sampling site and the approximate positions of the oil field areas (base map: made with Natural Earth).

Two phases of field campaigns were carried out in winterspring (from 9 February to 1 April) and summer (from 1 June to 10 July) 2017 at the YelRD Ecological Research Station of Coastal Wetland $\left(37.75^{\circ} \mathrm{N}, 118.97^{\circ} \mathrm{E} ; 1 \mathrm{~m}\right.$ above sea level), Chinese Academy of Sciences. This site lies roughly $32 \mathrm{~km}$ to the northeast of the Dongying urban area and $10 \mathrm{~km}$ to the west of the Bohai Sea (Fig. 1). It is a typical rural site surrounded by open oil fields and without any other anthropogenic emission sources nearby. There are two intensive oil production areas near the site. One is mainly distributed in the coastal area (about $10 \mathrm{~km}$ to the northeast), while the other is in the urban area (about $30 \mathrm{~km}$ to the southwest). In view of the regional scale, the observation site is constrained by both aged continental air masses transported from the Beijing-Tianjin-Hebei region and marine air from the Bohai Sea. Details of the sampling site can be found elsewhere (Zhang et al., 2019). Source samples were also collected from the nearby oil and gas wells to obtain the source profiles of VOCs from the oil field.

\subsection{Measurement techniques}

All in situ measurement instruments were housed in a temperature-controlled container, and the sampling inlets were mounted on top of the container with an altitude of about $5 \mathrm{~m}$ above the ground. A large suite of chemical species and meteorological parameters were measured. Briefly, $\mathrm{O}_{3}$ was monitored by an ultraviolet photometric analyzer (Thermo Environmental Instruments (TEI) model 49C). NO and $\mathrm{NO}_{y}$ were measured by a chemiluminescence instrument (Advanced Pollution Instrumentation (API) model T200U) equipped with an externally placed molybdenum oxide $(\mathrm{MoO})$ catalytic converter. $\mathrm{NO}_{2}$ was observed with a cavity attenuated phase shift (CAPS) analyzer that is highly selective for true $\mathrm{NO}_{2}$ (API, model T500U). $\mathrm{SO}_{2}$ was observed using a pulsed ultraviolet fluorescence analyzer (TEI, model 43C). CO was detected using a gas fil- ter correlation nondispersive infrared analyzer (API model 300U). These trace gas analyzers were calibrated manually every $3 \mathrm{~d}$ during the measurement campaigns, including zero and span checks as well as conversion efficiency calibration of the $\mathrm{MoO}$ catalytic converter, with additional zero calibration automatically done every $4 \mathrm{~h}$ for the $\mathrm{CO}$ instrument. The particle number size distributions between 5 and $350 \mathrm{~nm}$ were measured by a wide-range particle spectrometer (WPS, model 1000XP, MSP Corporation, USA), while those in the range of $300 \mathrm{~nm}$ to $10 \mu \mathrm{m}$ were monitored by a handheld particle counter (model 9306, TSI, USA). $\mathrm{PM}_{2.5}$ mass concentrations were measured using a synchronized hybrid ambient real-time particulate monitor (SHARP; Thermo Scientific model 5030). HONO was detected by a long-path absorption photometer named LOPAP (QUMA GmbH, Germany). Meteorological parameters including wind direction, wind speed, temperature, and relative humidity $(\mathrm{RH})$ were continuously observed by a weather station (PC-3, Jinzhou Sunshine). Photolysis frequencies of $\mathrm{H}_{2} \mathrm{O}_{2}$, $\mathrm{HCHO}$, HONO, $\mathrm{O}_{3}, \mathrm{NO}_{3}$, and $\mathrm{NO}_{2}$ were observed by a CCD-detector spectrometer (Metcon $\mathrm{GmbH}$, Germany). The time resolution was $1 \mathrm{~min}$ averaged for trace gases and photolysis frequency, $5 \mathrm{~min}$ averaged for meteorological parameters, and $30 \mathrm{~min}$ averaged for $\mathrm{PM}_{2.5}$.

Whole-air samples were collected with clean and evacuated $2 \mathrm{~L}$ stainless-steel canisters for quantification of methane and $\mathrm{C}_{2}-\mathrm{C}_{10}$ non-methane hydrocarbons (NMHCs). The samples were mainly collected on sunny days (with a small part on cloudy days) during selected pollution episodes, with each sample taken every $2-3 \mathrm{~h}$ for $30 \mathrm{~s}$ from 07:00 to 19:00 local time (LT) in June-July and from 06:00 to 21:00 LT in February-March. In addition, seven samples were taken at 00:00 LT during the winter-spring campaign. The purpose of such sampling strategy is to better recognize the VOC pollution characteristics in this area and to facilitate detailed modeling analysis of $\mathrm{O}_{3}$ pollution events. Whole-air samples were also collected exactly in the sur- 
roundings of oil wells and petrochemical industrial areas using the same method. A total of 111 ambient samples (including 58 samples in winter-spring and 53 samples in summer 2017) as well as 21 source samples (including 18 oil field samples and 3 petrochemical plant samples) were taken in this study. After sampling, concentrations of methane and $\mathrm{C}_{2}-\mathrm{C}_{10}$ NMHCs were then quantified by gas chromatography (GC) separation followed by flame ionization detection (FID), mass spectrometry detection (MSD), and electron capture detection (ECD) at the laboratory of the University of California at Irvine (UCI) (Simpson et al., 2010; Xue et al., 2013). The detection limit is $0.01 \mathrm{ppmv}$ for methane and 3 pptv for $\mathrm{C}_{2}-\mathrm{C}_{10}$ NMHCs (Simpson et al., 2010). Note that $\mathrm{O}_{3}$ scrubbers were not used ahead of the canisters during the sampling, and the sampled canisters were shipped to the UCI for analysis immediately after the individual field campaign. Some reactive VOC compounds (such as alkenes) may be decayed more or less during the time span from sampling to lab analysis. Thus, one should keep in mind that the VOC observations in this study may be subject to some uncertainty and the reactive compounds may be underestimated to some extent.

Carbonyl samples were collected by adsorption of ambient air in a 2,4-dinitrophenylhydrazine-coated sorbent cartridge (Waters Sep-Pak DNPH-silica) at a flow rate of $0.5 \mathrm{~L} \mathrm{~min}^{-1}$. An $\mathrm{O}_{3}$ scrubber was attached to the front of the cartridge to avoid $\mathrm{O}_{3}$ interference. The sampling strategy was similar to that of VOC canister samples. Specifically, the carbonyl samples were taken during selected episodes every $3 \mathrm{~h}$ from 06:00 to 21:00 LT in winter-spring and every $2 \mathrm{~h}$ from 07:00 to 19:00 LT in summer (the sampling time for each sample in winter-spring and summer was 3 and $2 \mathrm{~h}$, respectively). A total of 128 ambient samples (including 58 samples in winter-spring and 70 samples in summer) and 10 source samples were taken at the rural site and in the oil fields, respectively. After the campaign, the samples were analyzed with the high-performance liquid chromatography (HPLC) for quantification of $14 \mathrm{C}_{1}-\mathrm{C}_{8}$ carbonyl species (Yang et al., 2018).

All of the above measurement techniques have been successfully applied in many previous studies, and the detailed measurement principles, detection limits, quality assurance, and quality control procedures can be found elsewhere (Xue et al., 2016; Simpson et al., 2010; Yang et al., 2018; Li et al., 2018).

\subsection{Observation-based chemical box model}

The Observation-Based Model for investigating the Atmospheric Oxidation Capacity and Photochemistry (OBMAOCP) was used to simulate the in situ atmospheric photochemical processes and to quantify the $\mathrm{O}_{3}$ production rate, $\mathrm{OH}$ reactivity, and radical budgets $\left(\mathrm{RO}_{x}: \mathrm{OH}, \mathrm{HO}_{2}\right.$, and $\mathrm{RO}_{2}$ ). This model has been successfully adopted in many previous studies (e.g., L. K. Xue et al., 2014; Xue et al., 2016;
Yang et al., 2018; Li et al., 2018; Sun et al., 2018). In short, it is based on the latest version of the Master Chemical Mechanism (MCM v3.3.1), a nearly explicit mechanism describing the gas-phase chemical reactions that involve 143 primary VOC species (Saunders et al., 2003). In addition to the existing reactions in MCM v3.3.1, OBM-AOCP also incorporates over 200 reactions which represent the oxidation of VOCs by chlorine radical (Xue et al., 2015) and heterogeneous processes involving reactive nitrogen oxides (L. K. Xue et al., 2014). Physical processes such as dry deposition and dilution mixing in the boundary layer are also taken into account, and details can be found elsewhere (L. K. Xue et al., 2014).

OBM-AOCP is able to simultaneously quantify the $\mathrm{O}_{3}$ production rate, atmospheric oxidation capacity (AOC), $\mathrm{OH}$ reactivity, and the primary production, recycling, and termination rates of $\mathrm{RO}_{x}$ radicals. It tracks and calculates the individual reaction rate of almost all the reactions in the MCM, including the free radical chemistry. Among them, the sum of oxidation rates of various pollutants $\left(\mathrm{CO}, \mathrm{VOCs}, \mathrm{NO}_{x}\right.$, $\mathrm{SO}_{2}$, etc.) by the major oxidants (i.e., $\mathrm{OH}, \mathrm{O}_{3}, \mathrm{NO}_{3}$, and $\mathrm{Cl}$ ) is regarded as the AOC (Xue et al., 2016). The reaction rates of $\mathrm{OH}$ with $\mathrm{CO}, \mathrm{VOCs}, \mathrm{NO}_{x}, \mathrm{SO}_{2}, \mathrm{HONO}, \mathrm{HNO}_{3}$, and $\mathrm{HO}_{2} \mathrm{NO}_{2}$ are computed as the $\mathrm{OH}$ reactivity. Primary sources of $\mathrm{OH}, \mathrm{HO}_{2}$, and $\mathrm{RO}_{2}$ include the photolysis reactions of $\mathrm{O}_{3}$, HONO, formaldehyde, and other OVOCs as well as reactions of VOCs with $\mathrm{O}_{3}$ and $\mathrm{NO}_{3}$ radicals (Xue et al., 2016). Related reactions were grouped into a dozen major routes of production, recycling, and loss for quantifying the $\mathrm{RO}_{x}$ chemical budget (Xue et al., 2016). The $\mathrm{O}_{3}$ chemical budget was also quantified by the model. $\mathrm{O}_{3}$ production rate $\left(P\left(\mathrm{O}_{3}\right)\right)$ was calculated as the sum of reaction rates for $\mathrm{HO}_{2}+\mathrm{NO}$ and $\mathrm{RO}_{2}+\mathrm{NO}$ reactions (Eq. 1), and $\mathrm{O}_{3}$ loss rate $\left(L\left(\mathrm{O}_{3}\right)\right)$ was computed as the sum of reaction rates for $\mathrm{O}_{3}$ photolysis, $\mathrm{O}_{3}+\mathrm{OH}, \mathrm{O}_{3}+\mathrm{HO}_{2}, \mathrm{O}_{3}+\mathrm{VOCs}, \mathrm{NO}_{2}+\mathrm{OH}, \mathrm{NO}_{2}+\mathrm{RO}_{2}$ (minus the decomposition rate of organic nitrates), $\mathrm{NO}_{3}+\mathrm{VOCs}$, and loss of $\mathrm{N}_{2} \mathrm{O}_{5}$ (Eq. 2). The net $\mathrm{O}_{3}$ production rate can be calculated as the difference between $P\left(\mathrm{O}_{3}\right)$ and $L\left(\mathrm{O}_{3}\right)$ (Eq. 3). Here, $k_{i}$ is the corresponding reaction constant. Details of the above chemistry calculation can be found elsewhere (L. K. Xue et al., 2014; Xue et al., 2016).

$$
\begin{aligned}
& P\left(\mathrm{O}_{3}\right)=k_{1}\left[\mathrm{HO}_{2}\right][\mathrm{NO}]+\sum\left(k_{2}\left[\mathrm{RO}_{2}\right][\mathrm{NO}]\right) \\
& L\left(\mathrm{O}_{3}\right)=k_{3}\left[\mathrm{O}\left({ }^{1} \mathrm{D}\right)\right]\left[\mathrm{H}_{2} \mathrm{O}\right]+k_{4}\left[\mathrm{O}_{3}\right][\mathrm{OH}] \\
&+k_{5}\left[\mathrm{O}_{3}\right]\left[\mathrm{HO}_{2}\right]+\sum\left(k_{6 i}\left[\mathrm{O}_{3}\right]\left[\mathrm{VOC}_{i}\right]\right) \\
&+k_{7}[\mathrm{OH}]\left[\mathrm{NO}_{2}\right]+\sum\left(k_{8 i}\left[\mathrm{NO}_{2}\right]\left[\mathrm{RO}_{2 i}\right]\right) \\
&+2 \sum\left(k_{9 i}\left[\mathrm{NO}_{3}\right]\left[\mathrm{VOC}_{i}\right]\right)+3 k_{10}\left[\mathrm{~N}_{2} \mathrm{O}_{5}\right] \\
& \operatorname{Net} P\left(\mathrm{O}_{3}\right)=P\left(\mathrm{O}_{3}\right)-L\left(\mathrm{O}_{3}\right)
\end{aligned}
$$

Measured data of $\mathrm{O}_{3}, \mathrm{SO}_{2}, \mathrm{CO}, \mathrm{NO}, \mathrm{NO}_{2}, \mathrm{HONO}, J$ values, temperature, and $\mathrm{RH}$ were averaged to a time resolution of $5 \mathrm{~min}$ to constrain the model. In addition, measured concentrations of $\mathrm{CH}_{4}, \mathrm{C}_{2}-\mathrm{C}_{10} \mathrm{NMHCs}$, and $\mathrm{C}_{1}-\mathrm{C}_{8}$ carbonyl compounds were interpolated to a time resolution of $30 \mathrm{~min}$ 
for model inputs. For the nighttime data, when direct observations were generally unavailable, $\mathrm{CH}_{4}$ and $\mathrm{C}_{2}-\mathrm{C}_{10} \mathrm{NMHC}$ (except isoprene) concentrations were interpolated according to their linear regressions with $\mathrm{CO}$, and concentrations of isoprene were interpolated based on the linear relationship with temperature (Yang et al., 2018). The nighttime OVOC data were interpolated according to the multiple linear regressions with $\mathrm{CO}$ and $\mathrm{O}_{3}$ (Yang et al., 2018). Such approximation was mainly to facilitate the pre-run of the model and should not affect the formal daytime modeling results. Unmeasured photolysis frequencies within the model were calculated as a function of the solar zenith angle (Saunders et al., 2003) and then were scaled with the measured $J\left(\mathrm{NO}_{2}\right)$. The model starts at 00:00 LT and pre-runs for $4 \mathrm{~d}$ under constraints of input data to stabilize the species which were not measured in the field campaign, and the daytime modeling results of the last day were subject to further analyses.

\section{Overview of $\mathrm{O}_{3}$ and VOC pollution}

The overall air quality and meteorological conditions measured during the two-phase campaign are presented in Fig. 2. Descriptive statistics of major trace gases, aerosols, and meteorological parameters are summarized in Table 1. Seasonal variability of air pollution and weather is clearly illustrated. The winter and early spring (i.e., February-March) is featured by cold weather and higher levels of primary air pollutants. All the trace gases (except for $\mathrm{O}_{3}$ ) and $\mathrm{PM}_{2.5}$ showed significantly higher concentrations in February and March than in summer (June-July). This can be explained by the shallow boundary layer, less active photochemistry, and additional emissions from residential heating in winter-spring. In contrast, $\mathrm{O}_{3}$ exhibited much higher levels in summer, mainly corresponding to the more intense photochemical formation as a result of the hot weather and strong solar radiation. Elevated $\mathrm{O}_{3}$ concentrations were frequently observed during the summer campaign, with 22 non-attainment days (defined as the day when the maximum hourly $\mathrm{O}_{3}$ concentration exceeds China's National Ambient Air Quality Standard, Grade II, $93 \mathrm{ppbv}$ ) throughout the $40 \mathrm{~d}$ measurement period. The maximum hourly $\mathrm{O}_{3}$ value was recorded at $177 \mathrm{ppbv}$ in summer. These observations demonstrate the severity of photochemical air pollution in the YelRD region.

$\mathrm{O}_{3}$ pollution was also encountered in early spring. In March, $2 \mathrm{O}_{3}$ non-attainment days were identified with a maximum hourly $\mathrm{O}_{3}$ mixing ratio of $106 \mathrm{ppbv}$. When looking at the MDA8 $\mathrm{O}_{3}$, the number of non-attainment days (with MDA8 $\mathrm{O}_{3}$ exceeding 75 ppbv) increased to 5 in March 2017. However, no $\mathrm{O}_{3}$ episodes occurred in February. This is quite different from the recent observations in the US that have found very high levels of $\mathrm{O}_{3}$ in winter in the oil basin (Schnell et al., 2009; Edwards et al., 2014). We examined the observed chemical environments and weather conditions in the YelRD region. As detailed below, there were abun- dant $\mathrm{O}_{3}$ precursors, especially VOCs, in this study region, which would sustain as much as photochemical $\mathrm{O}_{3}$ formation. The major difference between this study and the US efforts lies in the weather conditions. As proposed by Ahmadov et al. (2015), snow cover is a prerequisite for the occurrence of wintertime $\mathrm{O}_{3}$ episodes in the US oil basins. During the wintertime observation period, the weather was quite dry and only small amounts of snowfall occurred during the nighttime of 21 February. The snow cover was very thin and it quickly disappeared with increase in temperature under the influence of a subsequent high-pressure system. Furthermore, the YelRD region is usually affected by strong winds in winter (Fig. 2) due to its flat and coastal topography. Thus, the meteorological conditions encountered in the present study were unfavorable for the occurrence of winter $\mathrm{O}_{3}$ episodes. Similarly, $\mathrm{O}_{3}$ episodes were also not observed in the Uintah Basin in the snow-free winter of 2012 (Edwards et al., 2014). More observations are still needed to examine the wintertime $\mathrm{O}_{3}$ issues in the oil extraction areas of China.

Table 2 documents the statistics of individual VOC species observed in the present study. Obviously, the ambient air in the YelRD region is very rich in VOCs, in particular alkanes, which accounted for the majority (i.e., $84.3 \%$ for winterspring and $70.6 \%$ for summer) of the measured NMHCs. Extremely high levels of VOCs were frequently observed at the study site, although it is located in a remote coastal area. The maximum concentrations of total NMHCs were 2823 and $176 \mathrm{ppbv}$ in winter-spring and summer, respectively. These samples were heavily affected by the gas leakage from the surrounding oil fields and will be discussed further in Sect. 4. In addition, elevated concentrations of light olefins such as ethene, propene, and butenes were also detected, especially during the winter and early spring when the photochemical oxidation was less active. This was mainly attributed to the emissions from refining industry in the YelRD region, which is well known as an important base for petrochemical industry in north China. A number of refining plants are indeed located to the southwest and north of the sampling site. Such a VOC-rich atmosphere is expected to efficiently facilitate $\mathrm{O}_{3}$ production with a certain amount of $\mathrm{NO}_{x}$. Furthermore, similar to other primary pollutants, all of the VOC compounds (except for cyclopentane and isoprene) showed a typical seasonal variation with higher concentrations in winter-spring and lower levels in summer.

Figures 3-4 present the average diurnal variation patterns of major trace gases (including VOCs), $\mathrm{PM}_{2.5}$, and meteorological parameters during the two campaigns. All the pollutants showed well-defined diurnal profiles that can be explained by the evolution of the planetary boundary layer, local emissions, and atmospheric photochemistry. Specifically, $\mathrm{O}_{3}$ showed a broad afternoon concentration peak with a trough in the early morning in both seasons. The other primary pollutants (e.g., $\mathrm{CO}, \mathrm{SO}_{2}$, and $\mathrm{NO}_{x}$ ) and $\mathrm{PM}_{2.5}$ exhibited higher concentrations in the morning and the lowest levels in the afternoon. VOCs generally showed higher levels 
Table 1. Descriptive statistics of hourly concentrations of trace gases, $\mathrm{PM}_{2.5}$, and meteorological parameters at the rural site in the YelRD region.

\begin{tabular}{lrrr|rrr}
\hline \multirow{2}{*}{ Species/parameter } & \multicolumn{3}{c|}{ February-March 2017 } & \multicolumn{3}{|c}{ June-July 2017 } \\
\cline { 2 - 7 } & Mean \pm SD & Median & Max & Mean \pm SD & Median & Max \\
\hline $\mathrm{O}_{3}$ (ppbv) & $34 \pm 17$ & 36 & 106 & $65 \pm 28$ & 60 & 177 \\
$\mathrm{CO}(\mathrm{ppbv})$ & $530 \pm 331$ & 463 & 2667 & $428 \pm 221$ & 373 & 1728 \\
$\mathrm{NO}(\mathrm{ppbv})$ & $1.39 \pm 3.11$ & 0.17 & 46.92 & $0.31 \pm 0.50$ & 0.17 & 19.03 \\
$\mathrm{NO}_{2}(\mathrm{ppbv})$ & $10.08 \pm 8.84$ & 7.50 & 55.34 & $3.47 \pm 3.34$ & 2.36 & 37.32 \\
$\mathrm{NO}_{y}(\mathrm{ppbv})$ & $19.84 \pm 16.40$ & 16.85 & 86.74 & $10.13 \pm 7.74$ & 8.44 & 69.58 \\
$\mathrm{SO}_{2}(\mathrm{ppbv})$ & $4.68 \pm 5.16$ & 2.99 & 44.68 & $2.10 \pm 2.71$ & 1.14 & 34.09 \\
$\mathrm{PM}_{2.5}\left(\mu \mathrm{g} \mathrm{m}^{-3}\right)$ & $66.7 \pm 56.4$ & 50.6 & 247 & $41.1 \pm 33.1$ & 31.5 & 167.9 \\
$\left.\mathrm{TEMP}^{\circ}\right)$ & $5.8 \pm 4.8$ & 5.8 & 18.6 & $25.9 \pm 4.5$ & 26.1 & 36.8 \\
$\mathrm{RH}(\%)$ & $69 \pm 18$ & 73 & 100 & $76 \pm 16$ & 82 & 99 \\
\hline
\end{tabular}

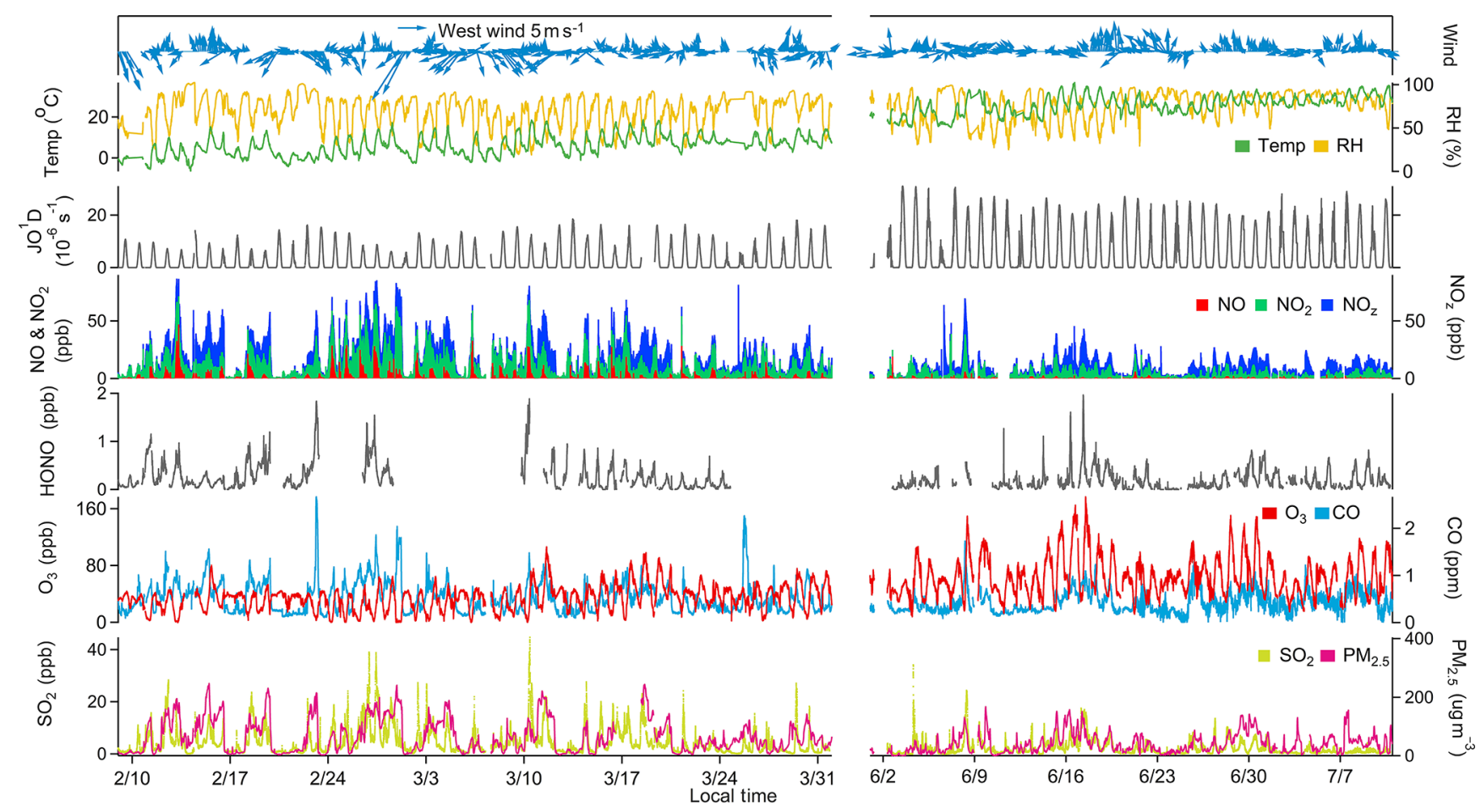

Figure 2. Time series of major trace gases, $\mathrm{PM}_{2.5}$, and meteorological parameters measured at the study site during February-March and June-July 2017.

during the nighttime or the early morning and lower mixing ratios during the day, with long-chain alkenes (comprising isoprene, 3-methyl-1-butene, 2-methyl-1-butene, alphapinene, and beta-pinene) as an exception that shows an opposite diurnal pattern in summer (Fig. 4). A noteworthy result is the fast accumulation of $\mathrm{O}_{3}$ during the morning period. For example, the average increases in $\mathrm{O}_{3}$ concentrations in the morning (06:00-12:00 LT) were 49.2 and 30.2 ppbv in summer and winter-spring, respectively. The early morning (i.e., 05:00-07:00 LT) $\mathrm{O}_{3}$ increase may be attributed to the downward intrusion of $\mathrm{O}_{3}$-laden residual layer air (see Fig. $\mathrm{S} 1$ in the Supplement), while the rapid $\mathrm{O}_{3}$ increase throughout the morning period suggests strong in situ photochemical formation in this VOC-rich area. This will be further quantified with the model in Sect. 6.

\section{Emission profiles of VOCs from oil fields}

To characterize the VOC emissions from the oil fields in China, 18 whole-air samples were taken exactly close to the oil extraction machines in the open oil fields. The data can provide direct insights into the composition profile of VOCs from Chinese oil field emissions. Regional background of 
Table 2. Descriptive statistics of measured VOC concentrations at the rural site in the YelRD region.

\begin{tabular}{|c|c|c|c|c|c|c|}
\hline \multirow[t]{2}{*}{ Compound } & \multicolumn{3}{|c|}{ February-March, 2017} & \multicolumn{3}{|c|}{ June-July, 2017} \\
\hline & Mean \pm SD & Median & Max & Mean \pm SD & Median & $\operatorname{Max}$ \\
\hline $\mathrm{CH}_{4}$ & $2116 \pm 159$ & 2084 & 2869 & $223 \pm 282$ & 2184 & 3704 \\
\hline Ethane & $7.094 \pm 4.143$ & 6.091 & 21.986 & $5.092 \pm 5.211$ & 3.394 & 29.878 \\
\hline Propane & $29.640 \pm 88.873$ & 5.380 & 470.670 & $5.740 \pm 7.448$ & 3.353 & 38.081 \\
\hline$i$-Butane & $24.456 \pm 87.067$ & 1.581 & 484.988 & $1.983 \pm 2.500$ & 1.155 & 14.660 \\
\hline$n$-Butane & $38.417 \pm 134.908$ & 2.546 & 732.394 & $3.399 \pm 4.579$ & 2.231 & 25.996 \\
\hline$i$-Pentane & $30.687 \pm 110.933$ & 1.361 & 585.862 & $1.693 \pm 2.334$ & 1.042 & 11.956 \\
\hline$n$-Pentane & $7.209 \pm 22.698$ & 0.909 & 123.655 & $1.213 \pm 1.782$ & 0.781 & 10.122 \\
\hline$n$-Hexane & $0.255 \pm 0.464$ & 0.093 & 2.337 & $0.324 \pm 0.510$ & 0.097 & 2.362 \\
\hline$n$-Heptane & $1.041 \pm 2.296$ & 0.315 & 11.441 & $0.394 \pm 0.575$ & 0.249 & 3.313 \\
\hline$n$-Octane & $0.518 \pm 1.376$ & 0.105 & 7.126 & $0.121 \pm 0.177$ & 0.071 & 0.951 \\
\hline$n$-Nonane & $0.167 \pm 0.383$ & 0.052 & 2.058 & $0.052 \pm 0.054$ & 0.036 & 0.314 \\
\hline$n$-Decane & $0.251 \pm 0.747$ & 0.046 & 3.586 & $0.042 \pm 0.029$ & 0.035 & 0.168 \\
\hline 2,3-Dimethylbutane & $0.097 \pm 0.220$ & 0.035 & 1.052 & $0.027 \pm 0.018$ & 0.021 & 0.092 \\
\hline 2-Methylpentane & $0.153 \pm 0.295$ & 0.052 & 1.529 & $0.069 \pm 0.102$ & 0.033 & 0.513 \\
\hline 3-Methylpentane & $0.646 \pm 1.366$ & 0.195 & 7.062 & $0.256 \pm 0.476$ & 0.121 & 2.769 \\
\hline 2,4-Dimethylpentane & $0.489 \pm 0.964$ & 0.179 & 4.411 & $0.183 \pm 0.300$ & 0.090 & 1.717 \\
\hline Cyclopentane & $0.187 \pm 0.476$ & 0.020 & 1.990 & $0.028 \pm 0.031$ & 0.014 & 0.134 \\
\hline Methylcyclopentane & $1.329 \pm 2.931$ & 0.361 & 12.773 & $0.369 \pm 0.402$ & 0.232 & 1.698 \\
\hline Cyclohexane & $2.081 \pm 6.728$ & 0.133 & 32.069 & $0.136 \pm 0.213$ & 0.067 & 1.112 \\
\hline Methylcyclohexane & $0.441 \pm 1.143$ & 0.090 & 5.376 & $0.129 \pm 0.191$ & 0.056 & 0.920 \\
\hline Ethene & $2.203 \pm 1.311$ & 2.013 & 5.925 & $1.076 \pm 1.047$ & 0.709 & 4.662 \\
\hline Propene & $1.362 \pm 2.283$ & 0.588 & 14.442 & $0.624 \pm 1.344$ & 0.163 & 8.805 \\
\hline 1-Butene & $0.203 \pm 0.376$ & 0.069 & 1.711 & $0.085 \pm 0.244$ & 0.025 & 1.627 \\
\hline$i$-Butene & $0.878 \pm 1.428$ & 0.254 & 4.472 & $0.055 \pm 0.074$ & 0.034 & 0.491 \\
\hline trans-2-Butene & $0.110 \pm 0.130$ & 0.042 & 0.461 & $0.027 \pm 0.036$ & 0.011 & 0.107 \\
\hline cis-2-Butene & $0.094 \pm 0.099$ & 0.054 & 0.360 & $0.050 \pm 0.058$ & 0.028 & 0.135 \\
\hline 1,3-Butadiene & $0.084 \pm 0.092$ & 0.047 & 0.324 & $1.317 \pm 3.880$ & 0.022 & 11.664 \\
\hline Isoprene & $0.112 \pm 0.219$ & 0.032 & 0.929 & $2.738 \pm 1.701$ & 2.497 & 7.113 \\
\hline 3-Methyl-1-butene & $0.036 \pm 0.034$ & 0.022 & 0.120 & $0.024 \pm 0.019$ & 0.016 & 0.061 \\
\hline 2-Methyl-1-butene & $0.046 \pm 0.052$ & 0.029 & 0.255 & $0.025 \pm 0.026$ & 0.012 & 0.071 \\
\hline alpha-Pinene & $0.424 \pm 1.345$ & 0.021 & 5.700 & $0.015 \pm 0.005$ & 0.014 & 0.028 \\
\hline beta-Pinene & $0.122 \pm 0.125$ & 0.026 & 0.291 & $0.020 \pm 0.012$ & 0.015 & 0.037 \\
\hline Ethyne & $3.055 \pm 1.964$ & 2.868 & 13.553 & $2.261 \pm 1.759$ & 1.731 & 8.450 \\
\hline Benzene & $1.073 \pm 0.567$ & 1.064 & 2.537 & $0.709 \pm 0.533$ & 0.539 & 2.852 \\
\hline Toluene & $14.378 \pm 50.177$ & 0.828 & 250.922 & $0.507 \pm 0.510$ & 0.285 & 2.317 \\
\hline Ethylbenzene & $0.648 \pm 1.781$ & 0.157 & 9.058 & $0.107 \pm 0.099$ & 0.078 & 0.632 \\
\hline$m / p$-Xylene & $1.542 \pm 4.599$ & 0.260 & 21.785 & $0.157 \pm 0.184$ & 0.090 & 1.117 \\
\hline$o$-Xylene & $0.573 \pm 1.662$ & 0.104 & 7.440 & $0.072 \pm 0.075$ & 0.047 & 0.465 \\
\hline Styrene & $0.173 \pm 0.339$ & 0.034 & 1.507 & $0.036 \pm 0.054$ & 0.016 & 0.216 \\
\hline$i$-Propylbenzene & $0.096 \pm 0.201$ & 0.019 & 0.732 & $0.029 \pm 0.020$ & 0.020 & 0.083 \\
\hline$n$-Propylbenzene & $0.118 \pm 0.282$ & 0.028 & 1.113 & $0.023 \pm 0.018$ & 0.016 & 0.084 \\
\hline$m$-Ethyltoluene & $0.269 \pm 0.757$ & 0.042 & 3.538 & $0.035 \pm 0.046$ & 0.019 & 0.232 \\
\hline$p$-Ethyltoluene & $0.164 \pm 0.387$ & 0.034 & 1.440 & $0.032 \pm 0.032$ & 0.022 & 0.154 \\
\hline$o$-Ethyltoluene & $0.175 \pm 0.385$ & 0.034 & 1.452 & $0.030 \pm 0.026$ & 0.020 & 0.111 \\
\hline 1,3,5-Trimethylbenzene & $0.197 \pm 0.423$ & 0.030 & 1.447 & $0.031 \pm 0.025$ & 0.023 & 0.081 \\
\hline $1,2,4$-Trimethylbenzene & $0.290 \pm 0.804$ & 0.047 & 3.748 & $0.042 \pm 0.055$ & 0.022 & 0.254 \\
\hline 1,2,3-Trimethylbenzene & $0.108 \pm 0.180$ & 0.038 & 0.743 & $0.032 \pm 0.025$ & 0.019 & 0.099 \\
\hline Total NMHC & $171.177 \pm 527.177$ & 30.041 & 2823.177 & $29.706 \pm 30.278$ & 23.189 & 175.661 \\
\hline
\end{tabular}

Units: ppbv. 


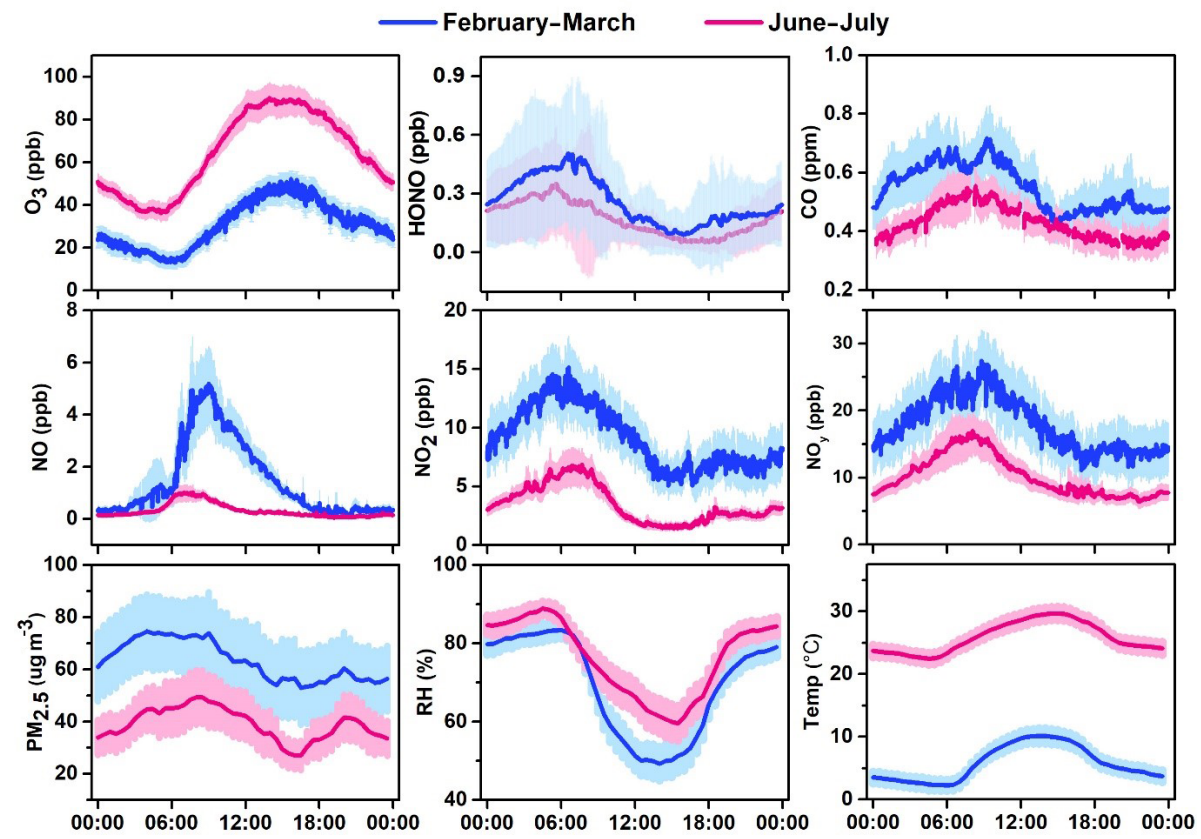

Figure 3. Average diurnal patterns of major trace gases, $\mathrm{PM}_{2.5}$, and meteorological parameters at the study site during February-March and June-July 2017. Error bars indicate the half standard deviation of the mean (blue line: February-March; red line: June-July).

VOC species was calculated as the average of the lowest 10th percentile of measurement data at the study site and was subtracted from the oil field source data to derive the VOC emission profiles. Figure 5 shows the measured oil field emission profiles of VOCs in the YelRD region. It is obvious that oil field emissions are dominated by alkanes. On a concentration basis, light alkanes $\left(\mathrm{C}_{2}-\mathrm{C}_{5}\right)$, long-chain alkanes $\left(\mathrm{C}_{6}-\mathrm{C}_{10}\right)$, alkenes, and aromatics account for $83.7 \%, 8.7 \%, 3.1 \%$, and $2.9 \%$ of the total measured NMHCs, respectively. The top 10 abundant species (in proportion) are propane $(25.3 \%)$, ethane $(22.1 \%), n$-butane $(13.6 \%), i$-butane $(8.3 \%), i$ pentane $(7.8 \%), n$-pentane $(6.0 \%)$, ethene $(1.9 \%), n$-hexane $(1.8 \%)$, ethyne (1.6\%), and 2-methylpentane (1.3\%).

Note that all the aforementioned calculations are based on the median VOC emission profile shown in Fig. 5. Since alkanes are major components of crude oil and natural gas, measured oil field emissions in this study are believed to be due to the leakage of oil and natural gas in this oil field region. To our knowledge, this should be the first direct measurement of oil field VOC emission profiles in China, which is valuable for better understanding the emissions of $O \& N G$ production and can be used for future air quality modeling studies.

Figure 6 compares the oil field emission profile in the YelRD region with those obtained from measurements adjacent to or surrounded by US oil fields. Overall, the measured VOC speciation patterns agree well with each other, although the absolute VOC concentrations vary case by case. For example, the VOC concentrations in the oil field in this study are generally higher than or comparable to those in the Fort Worth Basin, Denver-Julesburg Basin, and Upper Green River basin, but they are much lower than those measured in the Uintah Basin during wintertime $\mathrm{O}_{3}$ episodes. Such differences should be mainly caused by different atmospheric dilution conditions during the sampling campaigns. The extremely high VOC levels in the Uintah Basin can be ascribed to the strong inversion under unfavorable weather conditions (Neemann et al., 2015). There are also some differences in the detailed VOC speciation between the YelRD oil field emissions and those in US. The fraction of $\mathrm{C}_{2}-\mathrm{C}_{5}$ light alkanes in the YelRD oil fields was lower than those in the Uintah Basin (93.9\%), Fort Worth Basin (90.4\%), and Denver-Julesburg Basin (92.9\%) (ERG, 2011; Gilman et al., 2013; Koss et al., 2015). In comparison, the loadings of longchain alkanes $(8.7 \%)$ and aromatics $(2.9 \%)$ were higher in the YelRD oil field than in the US oil basins (4.2\%-6.9\% for long-chain alkanes, $<1.6 \%$ for aromatics). Such VOC speciation was attributed to the fact that oil extraction, rather than natural gas production, dominates in this study area.

As mentioned above, the ambient air at the sampling site may be influenced by the oil field emissions significantly. To verify this issue, all the ambient VOC data were subject to the Tukey test (Seo, 2006), and 11 samples were identified as "abnormal" sample. According to the VOC concentrations and speciation, the ambient VOC samples can be classified into three categories. Type 1 contains four abnormal samples and these samples have the highest concentrations for most species, especially alkanes, butenes, and aromatics (Fig. 6). Type 2 includes seven abnormal samples which have almost the same chemical speciation and absolute concentra- 

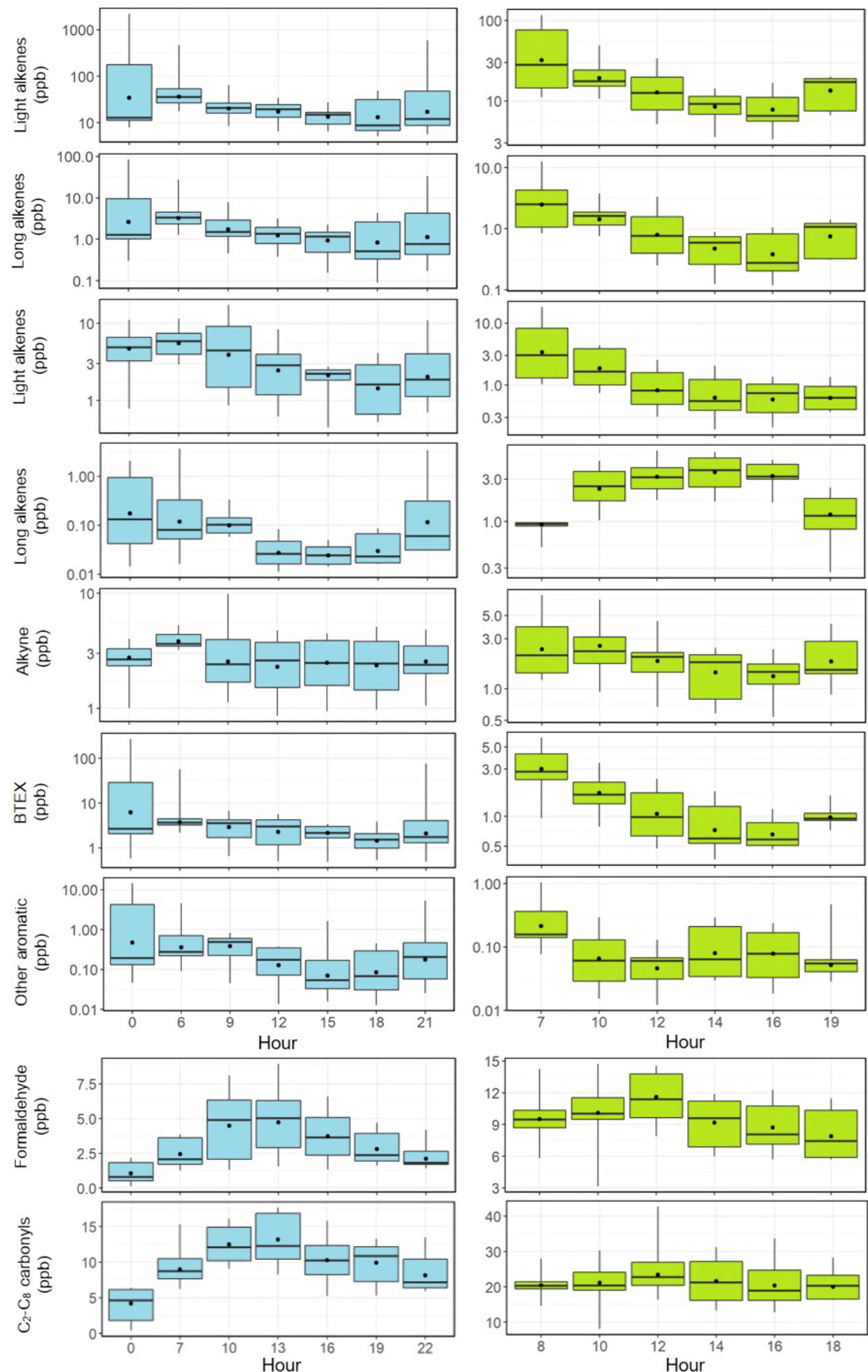

Figure 4. Average diurnal variations in light alkanes, long-chain alkanes, light alkenes, long-chain alkenes, alkyne, BTEX, other aromatics, formaldehyde, and $\mathrm{C}_{2}-\mathrm{C}_{8}$ carbonyls at the study site (left column: February-March; right column: June-July). The box plot provides the 5th, 25th, 50th, 75th, and 95th percentiles of the measurement data. 


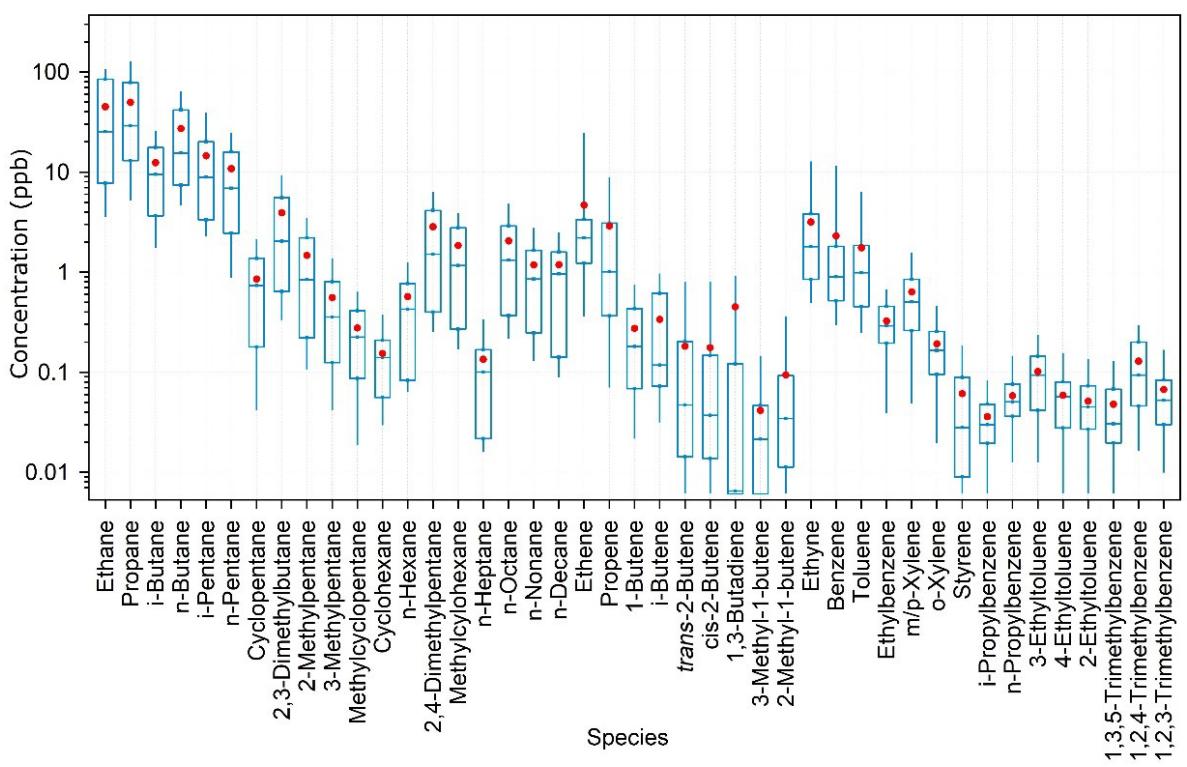

Figure 5. VOC source profile of the oil field emissions in the YelRD region. The box plot provides the 10th, 25th, 50th, 75th, and 90th percentiles of the source sample data, and the red dot gives the average of the data. Note that the regional background has been subtracted from the source data.

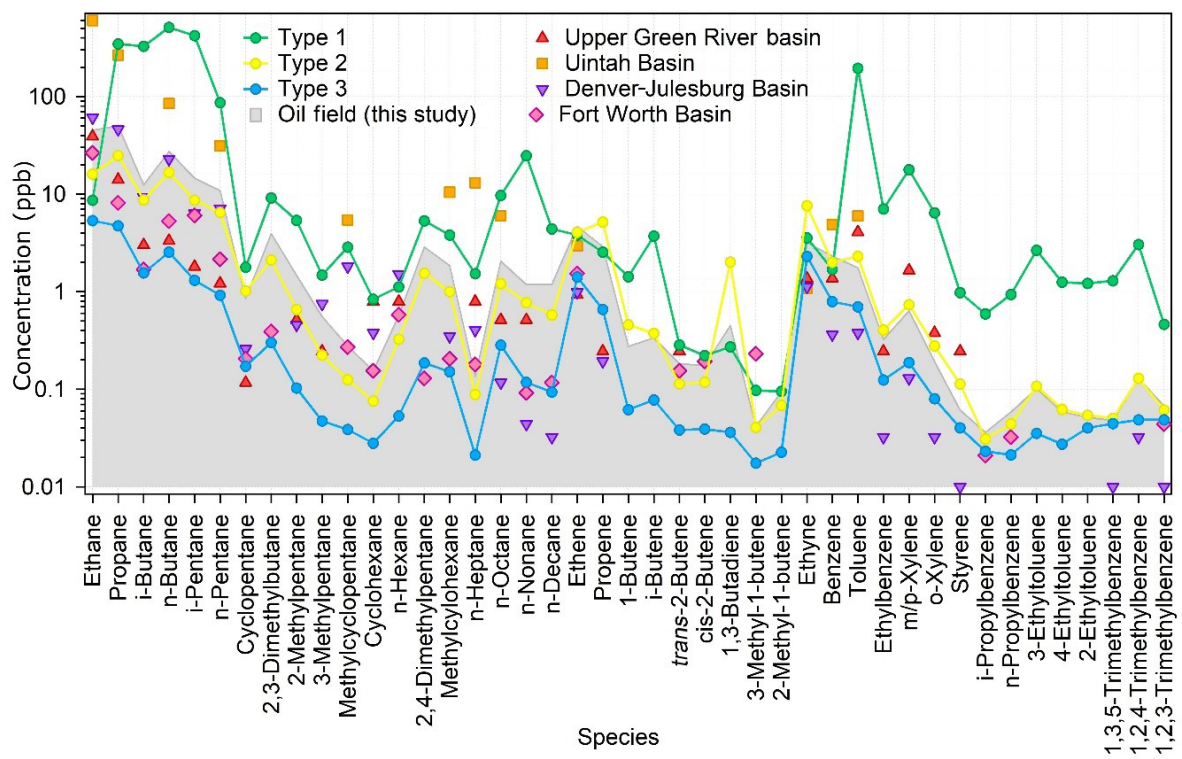

Figure 6. Comparison of the VOC composition of oil field samples (grey area) with three types of ambient samples in this study and in four US oil fields (ERG, 2011; Field et al., 2015; Gilman et al., 2013; Koss et al., 2015).

tions (only with slightly lower levels of light alkanes) as the oil field emission profiles (Fig. 6). The remaining 100 "normal" samples are classified as Type 3. Compared with the oil field emission profile, they have similar chemical speciation but lower concentrations. In terms of the sampling time, Types 1 and 2 samples were mainly collected in the early morning or at midnight, whilst most of the Type 3 samples were taken during the daytime. Figure 7 shows the scatter plots of $i$-pentane versus $n$-pentane for the three identified ambient VOC types as well as the oil field source data. Because $i$-pentane is generally recognized as tracer of gasoline, the ratio of $i$-pentane / $n$-pentane can be adopted to diagnose the potential impact of O\&NG operations on the VOC measurements in the O\&NG extraction region (Gilman et al., 2013). As shown in Fig. 7, Type 2 (1.2) and Type 3 (1.3) samples have comparable $i$-pentane $/ n$-pentane ratios to the oil field source data (1.0). Meanwhile, Type 1 samples have a much higher ratio of 4.5 , which is similar to the signature 


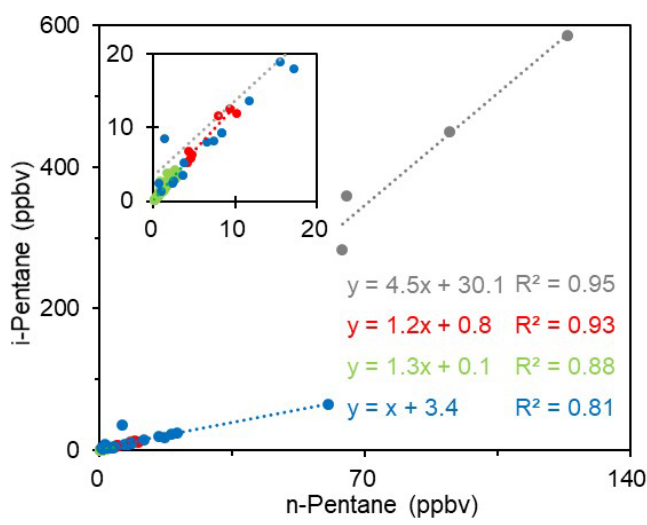

Figure 7. Scatter plot and regression lines of $i$-pentane versus $n$ pentane for the three types of ambient samples and oil field samples (grey: Type 1; red: Type 2; green: Type 3; blue: source; refer to the main text for the description of different types of data).

of gasoline emissions (4.87) (Lu and Zhang, 2003). In view of the above analyses, we propose that Type 1 samples were affected by short-term leakage from the surrounding refinery and oil storage areas, Type 2 samples were heavily influenced by the O\&NG extraction activities in the oil fields, and the normal Type 3 samples were also affected by the O\&NG extraction in this region. This indicates that the VOC-rich environment in the YelRD region is mainly influenced by the O\&NG extraction activities.

\section{Atmospheric oxidation capacity and radical chemistry}

In the following sections, we examine the detailed photochemical processes that occurred during the $\mathrm{O}_{3}$ pollution episodes. $\mathrm{As}_{3}$ episodes were mainly encountered during the summer campaign, here we focus on the summertime pollution events (with the modeling results for winter-spring provided in the Supplement). Nine severe $\mathrm{O}_{3}$ episodes (i.e., $8,9,14,15,16,18,29$, and 30 June and 9 July 2017) with the maximum hourly $\mathrm{O}_{3}$ concentrations exceeding $100 \mathrm{ppbv}$ and with concurrent comprehensive observation data were sorted out for chemical box modeling analyses. Detailed chemical budgets of $\mathrm{RO}_{x}$ radicals and $\mathrm{O}_{3}$ were quantified by the OBMAOCP. Simulation results for different cases were generally similar. Below we present the results that have been averaged across all selected episodes.

Figure 8 shows the average diurnal variations in $\mathrm{OH}$ and $\mathrm{HO}_{2}$ during the $\mathrm{O}_{3}$ episode days. High levels of $\mathrm{HO}_{x}$ radicals were simulated by the model. The daily maxima of $\mathrm{OH}$ and $\mathrm{HO}_{2}$ concentrations were 4.7-7.0 $\times 10^{6}$ and 10.3$14.1 \times 10^{8}$ molec. $\mathrm{cm}^{-3}$, with mean values of $5.9 \times 10^{6}$ and $12.5 \times 10^{8}$ molec. $\mathrm{cm}^{-3}$, respectively. Model-predicted concentrations of $\mathrm{HO}_{x}$ radicals in the rural area of YelRD are higher than those at Heshan (a rural site in the Pearl River

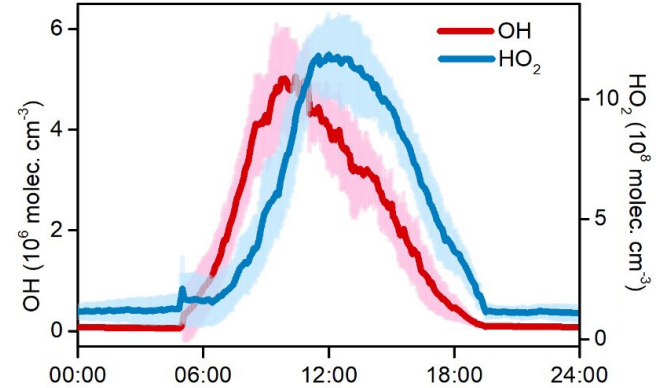

Figure 8. Simulated average diurnal variations in $\mathrm{OH}$ and $\mathrm{HO}_{2}$ during the nine $\mathrm{O}_{3}$ pollution episodes. The shaded areas indicate the standard deviations of the mean.

Delta, southern China) and Mace Head (a coastal site in Ireland) (Smith et al., 2006; Tan et al., 2019a). Comparable noontime maxima $\mathrm{HO}_{x}$ concentrations were observed at a rural site in the North China Plain (NCP) region (Wangdu; Tan et al., 2017) and in some polluted urban areas, such as Tokyo and Houston (Kanaya et al., 2007; Mao et al., 2010). This demonstrates the strong potential of atmospheric oxidation in the YelRD region. A noteworthy result is the $\mathrm{OH}$ concentration peak occurring in the morning (at around 10:00 LT), which is different from the most common results showing noontime $\mathrm{OH}$ peaks with intense solar radiation (Rohrer and Berresheim, 2006). To a large extent, the diurnal pattern of $\mathrm{OH}$ follows that of $\mathrm{NO}$ (see Fig. 3), suggesting the important role of $\mathrm{NO}$ in $\mathrm{OH}$ chemistry at the sampling site. Considering the VOC-rich conditions and relatively low levels of $\mathrm{NO}_{x}$ (e.g., observed average concentrations of $\mathrm{NO}$ are 0.43 and $0.23 \mathrm{ppb}$ during 09:00-12:00 and 12:00-16:00 LT, respectively), efficient radical propagation of $\mathrm{OH} \rightarrow \mathrm{RO}_{2} \rightarrow \mathrm{HO}_{2}$ is expected and the abundance of NO should be the limiting factor in the recycling of $\mathrm{HO}_{2}$ to $\mathrm{OH}$. The higher ratios of $\mathrm{HO}_{2} / \mathrm{OH}(\sim 257)$ in this study also indicate that the $\mathrm{HO}_{2}+\mathrm{NO} \rightarrow \mathrm{NO}_{2}+\mathrm{HO}$ reaction is the rate-determining step of the radical recycling. A similar phenomenon was also found at Backgarden (a VOC-saturated and $\mathrm{NO}_{x}$-limited environment) in the Pearl River Delta (PRD) region (Lu et al., 2012).

The strong atmospheric oxidation capacity (AOC, defined as the oxidation rates of all reduced substances by major oxidants) was confirmed by the model calculation and is shown in Fig. 9. The daily maxima and daily mean values of AOC during the selected episodes were in the range of $0.7-$ $1.8 \times 10^{8}$ and $2.6-4.8 \times 10^{7}$ molec. $\mathrm{cm}^{-3} \mathrm{~s}^{-1}$, respectively. AOC levels in the YelRD region are comparable to those obtained in some urban areas (Elshorbany et al., 2009; Xue et al., 2016) but are higher than that derived from rural areas (Geyer et al., 2001; Li et al., 2018). As expected, $\mathrm{OH}$ is the predominant oxidant during the daytime, accounting for $85.3 \pm 16.4 \%$ of $\mathrm{AOC} . \mathrm{NO}_{3}$ is the major oxidant at nighttime (18:00-06:00 LT), contributing $46.8 \pm 17.1 \%$ of nocturnal 


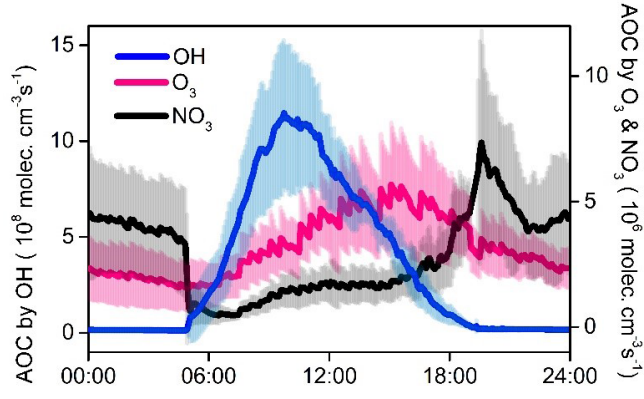

Figure 9. Model-calculated average oxidation capacity of $\mathrm{OH}, \mathrm{O}_{3}$, and $\mathrm{NO}_{3}$ during the summertime $\mathrm{O}_{3}$ pollution episodes. The error bars indicate the standard deviations of the mean.

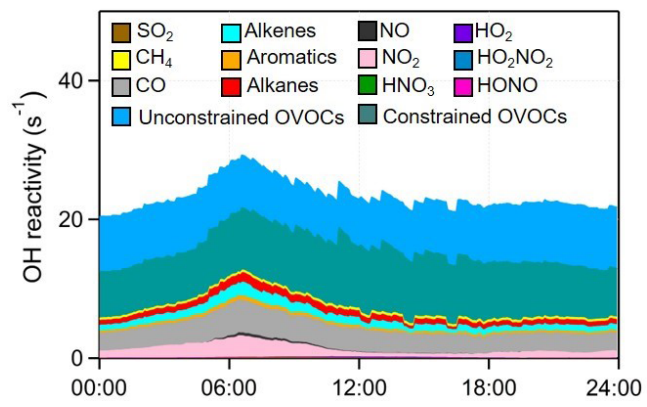

Figure 10. Model-calculated average $\mathrm{OH}$ reactivity $\left(K_{\mathrm{OH}}\right)$ and its breakdown to the major reactants during the summertime $\mathrm{O}_{3}$ pollution episodes.

AOC, followed by $\mathrm{O}_{3}(27.0 \pm 7.9 \%)$ and $\mathrm{OH}(26.2 \pm 17.8 \%)$. Figure 10 elucidates the $24 \mathrm{~h}$ evolution and partitioning of the chemical loss of $\mathrm{OH}$ radical (also known as the $\mathrm{OH}$ reactivity or $\left.K_{\mathrm{OH}}\right) . K_{\mathrm{OH}}$ in this study $\left(23.3 \pm 5.6 \mathrm{~s}^{-1}\right)$ is significantly higher than those determined from some rural sites such as Hok Tsui $\left(9.2 \pm 3.7 \mathrm{~s}^{-1}\right.$; Li et al., 2018), Nashville $\left(11.3 \pm 4.8 \mathrm{~s}^{-1}\right.$; Martinez et al., 2003), and Whiteface Mountain $\left(5.6 \mathrm{~s}^{-1}\right.$; Ren et al., 2006a) and is comparable to that measured in some polluted areas like Beijing $\left(10-30 \mathrm{~s}^{-1}\right.$; Lu et al., 2013; Williams et al., 2016; Yang et al., 2017) and Guangzhou (20-50 s ${ }^{-1}$; Lou et al., 2010). OVOCs (including the measured carbonyls and model-simulated OVOCs) were the dominant contributor $(69.1 \pm 7.2 \%)$ to $K_{\mathrm{OH}}$. CO, $\mathrm{NO}_{x}$, alkenes, alkanes, and aromatics are the other important reactants, explaining $13.2 \pm 2.5 \%, 5.6 \pm 4.1 \%, 4.4 \pm 1.5 \%$, $3.6 \pm 1.2 \%$, and $1.6 \pm 0.5 \%$ of $K_{\mathrm{OH}}$, respectively. The relatively higher fraction of alkanes is probably due to the highly abundant alkanes in the YelRD region as a result of influences from the oil field emissions.

Figure 11 presents major primary sources of $\mathrm{OH}, \mathrm{HO}_{2}$, and $\mathrm{RO}_{2}$ radicals quantified in the YelRD region, and the detailed $\mathrm{RO}_{x}$ radical budget is summarized in Fig. 12. Photolysis of OVOCs is identified as the dominant primary $\mathrm{RO}_{x}$ radical source, with daytime $(06: 00-18: 00 \mathrm{LT})$ aver- age production rates of $2.15 \pm 1.40 \mathrm{ppbvh}^{-1}$ for $\mathrm{HO}_{2}$ (of which $1.10 \pm 0.79 \mathrm{ppbv} \mathrm{h}^{-1}$ is from formaldehyde alone) and $0.86 \pm 0.53 \mathrm{ppbv} \mathrm{h}^{-1}$ for $\mathrm{RO}_{2}$, respectively. $\mathrm{O}_{3}$ photolysis is the second largest source of $\mathrm{RO}_{x}$ and the predominant primary source of $\mathrm{OH}\left(1.22 \pm 1.10 \mathrm{ppbv} \mathrm{h}^{-1}\right)$. HONO photolysis is the third largest source and supplies $\mathrm{OH}$ at an average rate of $0.49 \pm 0.48 \mathrm{ppbh}^{-1}$ during the daytime. The contribution of HONO photolysis is higher than that of $\mathrm{O}_{3}$ photolysis in the early morning (e.g., before 09:00 LT) but then becomes significantly lower with the decrease in HONO concentrations and photochemical formation of $\mathrm{O}_{3}$. Note that the model was constrained by the observed HONO data. Ozonolysis reactions of unsaturated VOCs are also important radical sources, accounting for $0.26 \pm 0.11,0.17 \pm 0.07$, and $0.14 \pm 0.07 \mathrm{ppbv} \mathrm{h}^{-1}$ of $\mathrm{OH}, \mathrm{HO}_{2}$, and $\mathrm{RO}_{2}$, respectively, on a daytime average basis. $\mathrm{NO}_{3}+\mathrm{VOC}$ reactions are only a minor radical source (for $\mathrm{RO}_{2}$ only). The above analysis illustrates the significant role of OVOCs (both primary carbonyls and secondary compounds formed from oxidation of abundant VOCs) in the primary production of radicals and thus initiation of atmospheric oxidation processes. The dominance of photolysis of OVOCs in the atmospheric photochemistry was also found during the wintertime $\mathrm{O}_{3}$ episodes in the Uintah Basin (Edwards et al., 2014). In comparison, a recent study illustrated the importance of HONO and formaldehyde photolysis in four polluted Chinese megacities (Beijing, Shanghai, Guangzhou, and Chongqing), which accounted for $\sim 50 \%$ of the total primary $\mathrm{RO}_{x}$ source (Tan et al., 2019b).

As shown in Fig. 12, the radical recycling processes were generally efficient and approximately 4-6 times faster than the primary radical production. This is ascribed to the high abundances of VOCs in the study region, despite the restriction from the relatively low $\mathrm{NO}_{x}$ concentrations. In terms of radical termination, the cross reactions of radicals such as $\mathrm{HO}_{2}+\mathrm{HO}_{2}$ and $\mathrm{HO}_{2}+\mathrm{RO}_{2}$ were the most important processes with daytime average contributions of $0.55 \pm 0.48$ and $1.12 \pm 0.94 \mathrm{ppbv} \mathrm{h}^{-1}$, respectively. In comparison, the reactions of $\mathrm{RO}_{x}$ with $\mathrm{NO}_{x}$ (i.e., $\mathrm{OH}+\mathrm{NO}_{2}$ and $\mathrm{RO}_{2}+\mathrm{NO}$ ) contributed $1.19 \pm 1.62 \mathrm{ppbvh}^{-1}$ to the radical sink. Such results are not surprising given the VOC-rich and low- $\mathrm{NO}_{x}$ chemical environment at our study site. This is quite different from those derived from the polluted urban areas, where the $\mathrm{RO}_{x}+\mathrm{NO}_{x}$ reactions generally dominate the radical termination processes (Tan et al., 2019b). Overall, the radical budget analysis elucidates the strong atmospheric oxidation capacity, the importance of OVOCs, and the limiting role of $\mathrm{NO}_{x}$ in the VOC-rich atmosphere of the YelRD region.

We also examined the atmospheric oxidation capacity, $\mathrm{RO}_{x}$ radical budget, and $\mathrm{O}_{3}$ formation for eight winterspring cases, and the modeling results are documented in Figs. S2-S7. Note that few $\mathrm{O}_{3}$ episodes were encountered during the winter-spring campaign, and the cases were selected mainly because of the availability of multiple NMHC and carbonyl sampling data. The daily maximum hourly $\mathrm{O}_{3}$ 

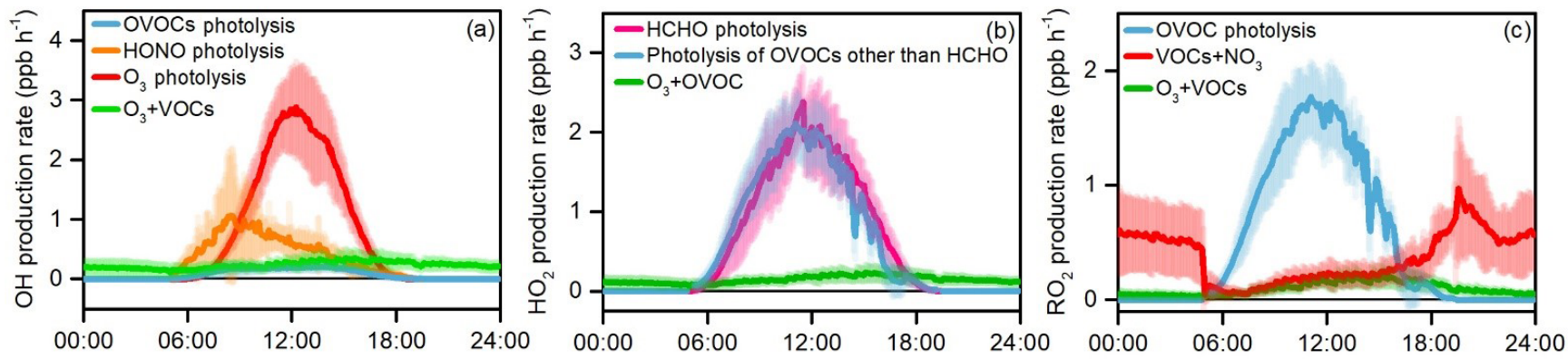

Figure 11. Simulated average primary production rates of (a) $\mathrm{OH}$, (b) $\mathrm{HO}_{2}$, and (c) $\mathrm{RO}_{2}$ during the summertime $\mathrm{O}_{3}$ pollution episodes. The error bars indicate the standard deviations of the mean.

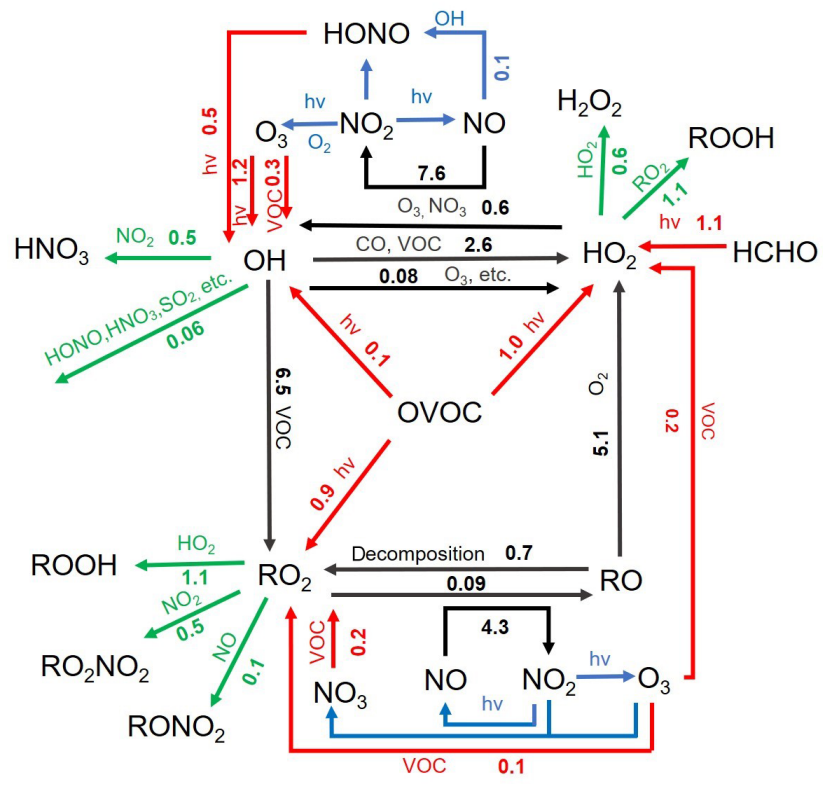

Figure 12. Daytime (06:00-18:00 LT) average $\mathrm{RO}_{x}$ budget during the summertime $\mathrm{O}_{3}$ episode days. The unit is parts per billion per hour. The red, green, and black lines indicate the production, destruction and recycling pathways of radicals, respectively.

concentrations during these cases were in the range of 40 98 ppbv. Several aspects are noteworthy from the modeling results for winter-spring. First, the model-simulated $\mathrm{HO}_{x}$ levels, $\mathrm{AOC}, \mathrm{RO}_{x}$ production and propagation rates, and $\mathrm{O}_{3}$ formation rate were much lower than those determined for the summertime episodes. This is as expected due to the weaker solar radiation and less active photochemistry in winter-spring than in summer. Second, $\mathrm{OH}$ showed a normal noontime concentration peak in winter-spring, which is different from the morning peak ( $\sim 10: 00 \mathrm{LT})$ found in summer (see Figs. 8 and S2). This was ascribed to the higher levels of $\mathrm{NO}_{x}$ at the study site in winter-spring (Fig. 3), which were high enough to maintain the radical recycling from $\mathrm{HO}_{2}$ to $\mathrm{OH}$. Third, the partitioning of the primary $\mathrm{RO}_{x}$ sources was generally similar between both seasons, despite the rel- atively lower contributions from the $\mathrm{O}_{3}$-involved sources (i.e., $\mathrm{O}_{3}$ photolysis and $\mathrm{O}_{3}+\mathrm{VOC}$ reactions). Photolysis of OVOCs other than formaldehyde was the dominant primary $\mathrm{RO}_{x}$ source, followed by HONO and formaldehyde photolysis. Fourth, the radical termination processes were different between winter-spring and summer. The dominant radical sinks were the cross reactions between $\mathrm{NO}_{x}$ and $\mathrm{RO}_{x}$ in winter-spring, as a result of the relatively abundant ambient $\mathrm{NO}_{x}$.

\section{Ozone formation mechanism}

We also examined the ozone formation mechanisms for the summertime episode days. Figure 13 shows the average detailed $\mathrm{O}_{3}$ chemical budgets during the nine cases. Strong photochemical formation of $\mathrm{O}_{3}$ was clearly illustrated, with daily maximum net $\mathrm{O}_{3}$ production rates of 14.5 $38.7 \mathrm{ppbv} \mathrm{h}^{-1}$ and daytime average rates (06:00-18:00 LT) of $9.8-19.6 \mathrm{ppbv} \mathrm{h}^{-1}$. The $\mathrm{O}_{3}$ production intensity in the rural area of the YelRD is higher than that derived from a rural site downwind of Beijing (Changping) and comparable to that in polluted suburban areas downwind of Shanghai and Lanzhou (L. K. Xue et al., 2014). Interestingly, the $\mathrm{O}_{3}$ production rate shows its maxima in the morning period (at around 10:00 LT) followed by a significant decrease in the afternoon, which differs from general results from previous studies showing noontime or afternoon peaks. This pattern is similar to that of $\mathrm{OH}$ and NO (Figs. 3 and 8) and should be due to the lower concentrations of NO in the afternoon. In the VOC-rich YelRD region, a certain amount of NO in the morning is enough to sustain efficient $\mathrm{O}_{3}$ production. In the afternoon, $\mathrm{NO}_{x}$ has been photochemically consumed due to its short lifetime and thus becomes the limiting factor in $\mathrm{O}_{3}$ formation (note that $\mathrm{O}_{3}$ production rate is defined as the reaction rates of $\mathrm{HO}_{2}+\mathrm{NO}$ and $\mathrm{RO}_{2}+\mathrm{NO}$ ). This also explains the observed unusual diurnal variation in $\mathrm{O}_{3}$ (Fig. 3), with a significant increase during the morning period and constant or reduced levels in the afternoon.

The relationships between $\mathrm{O}_{3}$ and its precursors were further diagnosed by the relative incremental reactivity (RIR) 


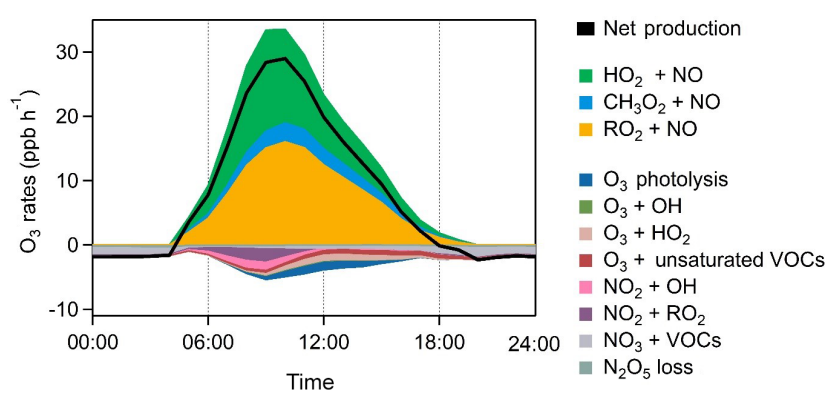

Figure 13. Model-simulated average chemical budgets of $\mathrm{O}_{x}$ during the selected $\mathrm{O}_{3}$ episodes.

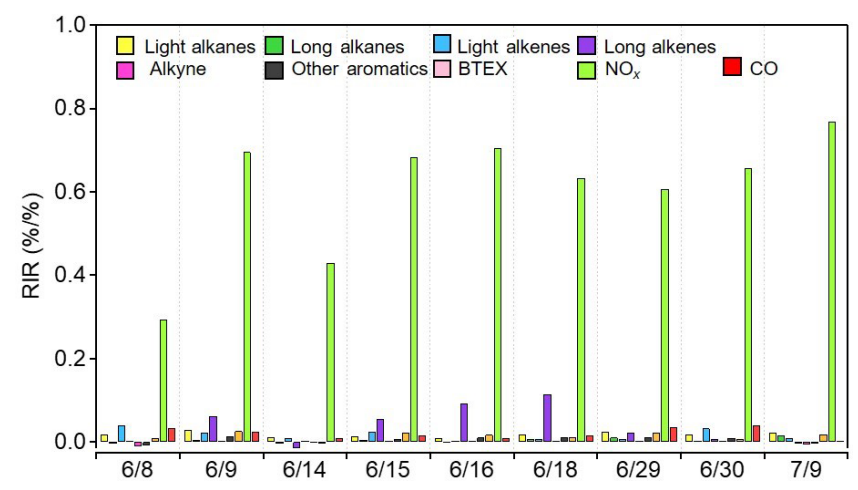

Figure 14. Model-calculated midday average (09:00-15:00 LT) RIRs for the major $\mathrm{O}_{3}$ precursor groups during the summertime $\mathrm{O}_{3}$ episodes.

calculation using the OBM-AOCP model. RIR is defined as the ratio of the change in $\mathrm{O}_{3}$ production rate to changes in precursor concentrations, and it can be used as an indicator for assessing the effect of precursor reduction on $\mathrm{O}_{3}$ formation (Cardelino and Chameides, 1995). A number of sensitivity modeling runs were conducted for individual episode days with $20 \%$ reduction in the input concentrations of each target $\mathrm{O}_{3}$ precursor group. As presented in Fig. 14, simulation results for most cases are similar. $\mathrm{O}_{3}$ production was most sensitive to $\mathrm{NO}_{x}$ concentrations, as indicated by the highest positive RIR values. This is expected as the aforementioned analyses suggest the limiting role of $\mathrm{NO}_{x}$ in radical recycling and $\mathrm{O}_{3}$ production. Alkenes, especially longchain alkenes, showed moderate positive RIR values, indicating they controlled $\mathrm{O}_{3}$ formation to some extent as well. Alkanes and aromatics are usually in high abundances owing to the extensive oil extraction in the YelRD region, showing minor RIR values, and were not the limiting factors for $\mathrm{O}_{3}$ formation. Overall, reducing $\mathrm{NO}_{x}$ emissions would be the most effective strategy for mitigating photochemical air pollution in the YelRD region.

Nonetheless, the oil field emissions of VOCs may have high potential to affect the regional air quality in the polluted YelRD and even the surrounding NCP regions, where ambient $\mathrm{NO}_{x}$ is usually abundant. The oil-field-emitted VOCs may significantly contribute to the formations of $\mathrm{O}_{3}$ and secondary organic aerosol on a regional scale. To address this issue, an oil field emission inventory of VOCs and $\mathrm{NO}_{x}$ as well as three-dimensional chemical transport model simulations are needed. So far, the oil field emissions have not been included by the emission inventories in China. More efforts are urgently needed to develop an accurate oil field emission inventory and evaluate their impacts on the regional air quality and climate.

\section{Conclusions}

We combined intensive field observations with chemical box modeling to understand the characteristics of VOC emissions from oil fields and their impacts on atmospheric chemistry and $\mathrm{O}_{3}$ pollution in the YelRD region, north China. Influenced by the O\&NG extraction and petrochemical industry, this area is characterized by a VOC-rich atmosphere with extremely high levels of alkanes. $\mathrm{O}_{3}$ pollution episodes occurred frequently in summertime. Meanwhile, no events were encountered in winter-spring because of the unfavorable weather conditions for $\mathrm{O}_{3}$ formation. The VOC chemical speciation from the oil field emissions was detected for the first time in China in this study. Driven by the high abundances of VOCs on a regional scale, strong atmospheric oxidation capacity and intense $\mathrm{O}_{3}$ formation were confirmed by observation-based modeling analyses. OVOCs played a dominant role in $\mathrm{OH}$ reactivity and hence radical recycling and were the major primary source of $\mathrm{RO}_{x}$ radicals. Photolysis of $\mathrm{O}_{3}$ and HONO was also found to be an important radical source. The radical termination processes were governed by radical cross reactions under the high-VOC and low- $\mathrm{NO}_{x}$ conditions. RIR analysis indicated that $\mathrm{O}_{3}$ formation was mainly in a $\mathrm{NO}_{x}$-controlled regime, and reducing $\mathrm{NO}_{x}$ emissions would be an effective way to control $\mathrm{O}_{3}$ pollution in the YelRD region. In summary, this study emphasized the key role of O\&NG extraction in the photochemical air pollution and regional atmospheric chemistry in the oil extraction regions of China, and the results are helpful for formulating anti-pollution strategies in the YelRD and other similar oil-extracting regions.

Data availability. The data that support the results are available from the corresponding author upon request.

Supplement. The supplement related to this article is available online at: https://doi.org/10.5194/acp-20-7069-2020-supplement.

Author contributions. LX designed the study. TC, PZ, YL, JS, and HYL conducted the field campaigns. GH provided logistics for the field campaigns. HL, XZ, and YL analyzed the OVOC samples. TC analyzed the measurement data. TC and $\mathrm{YZ}$ conducted the chemical 
box modeling analyses. TC and LX wrote the paper. GH, DC, HL, FX, QZ, and WW revised the manuscript.

Competing interests. The authors declare that they have no conflict of interest.

Acknowledgements. The authors thank Changli Yang, Rui Li, and Xinfeng Wang for their help in the field study, and thank Zeyuan Li and Xue Yang for their efforts in data analysis and discussion. We thank Donald Blake from the University of California at Irvine for the laboratory analyses of VOC samples, and we appreciate the University of Leeds for provision of the MCM v3.3.1. This study is funded by the National Natural Science Foundation of China (grant no. 41675118), Shandong Provincial Science Fund for Distinguished Young Scholars (ZR2019JQ09), Shenzhen Science and Technology Research and Development Funds Grant (JCYJ20160510165106371), the Qilu Youth Talent Programme of Shandong University, the Jiangsu Collaborative Innovation Center for Climate Change, and the Taishan Scholars (ts201712003). We thank the two anonymous referees for their helpful comments and suggestions to improve the original manuscript.

Financial support. This research has been supported by the National Natural Science Foundation of China (grant no. 41675118), the Shandong Provincial Science Fund for Distinguished Young Scholar (grant no. ZR2019JQ09), the Shenzhen Science and Technology Research and Development Funds Grant (grant no. JCYJ20160510165106371), the Qilu Youth Talent Programme of Shandong University, the Jiangsu Collaborative Innovation Center for Climate Change, and the Taishan Scholars (grant no. ts201712003).

Review statement. This paper was edited by Rupert Holzinger and reviewed by two anonymous referees.

\section{References}

Adgate, J. L., Goldstein, B. D., and McKenzie, L. M.: Potential public health hazards, exposures and health effects from unconventional natural gas development, Environ. Sci. Technol., 48, 8307-8320, https://doi.org/10.1021/es404621d, 2014.

Ahmadov, R., McKeen, S., Trainer, M., Banta, R., Brewer, A., Brown, S., Edwards, P. M., de Gouw, J. A., Frost, G. J., Gilman, J., Helmig, D., Johnson, B., Karion, A., Koss, A., Langford, A., Lerner, B., Olson, J., Oltmans, S., Peischl, J., Pétron, G., Pichugina, Y., Roberts, J. M., Ryerson, T., Schnell, R., Senff, C., Sweeney, C., Thompson, C., Veres, P. R., Warneke, C., Wild, R., Williams, E. J., Yuan, B., and Zamora, R.: Understanding high wintertime ozone pollution events in an oil- and natural gasproducing region of the western US, Atmos. Chem. Phys., 15, 411-429, https://doi.org/10.5194/acp-15-411-2015, 2015.

Allen, D. T., Torres, V. M., Thomas, J., Sullivan, D. W., Harrison, M., Hendler, A., Herndon, S. C., Kolb, C. E., Fraser,
M. P., Hill, A. D., and Lamb, B. K.: Measurements of methane emissions at natural gas production sites in the United States, P. Natl. Acad. Sci. USA, 110, 17768-17773, https://doi.org/10.1073/pnas.1304880110, 2013.

Alvarez, R. A., Pacala, S. W., Winebrake, J. J., Chameides, W. L., and Hamburg, S. P.: Greater focus needed on methane leakage from natural gas infrastructure, P. Natl. Acad. Sci. USA, 109, 6435-6440, https://doi.org/10.1073/pnas.1202407109, 2012.

British Petroleum Company plc.: BP statistical review of world energy 2018, available at: https://www.bp.com/content/dam/ bp/business-sites/en/global/corporate/pdfs/energy-economics/ statistical-review/bp-stats-review-2018-full-report.pdf （last access: 13 August 2019), 2018.

Cardelino, C. and Chameides, W.: An observation-based model for analyzing ozone precursor relationships in the urban atmosphere, J. Air Waste Manage., 45, 161-180, https://doi.org/10.1080/10473289.1995.10467356, 1995.

Carter, W. P. and Seinfeld, J. H.: Winter ozone formation and VOC incremental reactivities in the Upper Green River Basin of Wyoming, Atmos. Environ., 50, 255-266, https://doi.org/10.1016/j.atmosenv.2011.12.025, 2012.

Colborn, T., Schultz, K., Herrick, L., and Kwiatkowski, C.: An exploratory study of air quality near natural gas operations, Hum. Ecol. Risk Assess., 20, 86-105, https://doi.org/10.1080/10807039.2012.749447, 2014.

Dang, J., Shi, X., Hu, J., Chen, J., Zhang, Q., and Wang, W.: Mechanistic and kinetic studies on $\mathrm{OH}$-initiated atmospheric oxidation degradation of benzo $[\alpha]$ pyrene in the presence of $\mathrm{O}_{2}$ and $\mathrm{NO}_{x}$, Chemosphere, 119, 387-393, https://doi.org/10.1016/j.chemosphere.2014.07.001, 2015.

Ding, A. J., Wang, T., Thouret, V., Cammas, J.-P., and Nédélec, P.: Tropospheric ozone climatology over Beijing: analysis of aircraft data from the MOZAIC program, Atmos. Chem. Phys., 8, 1-13, https://doi.org/10.5194/acp-8-1-2008, 2008.

Edwards, P. M., Young, C. J., Aikin, K., deGouw, J., Dubé, W. P., Geiger, F., Gilman, J., Helmig, D., Holloway, J. S., Kercher, J., Lerner, B., Martin, R., McLaren, R., Parrish, D. D., Peischl, J., Roberts, J. M., Ryerson, T. B., Thornton, J., Warneke, C., Williams, E. J., and Brown, S. S.: Ozone photochemistry in an oil and natural gas extraction region during winter: simulations of a snow-free season in the Uintah Basin, Utah, Atmos. Chem. Phys., 13, 8955-8971, https://doi.org/10.5194/acp13-8955-2013, 2013.

Edwards, P. M., Brown, S. S., Roberts, J. M., Ahmadov, R., Banta, R. M., Degouw, J. A., Dubé, W. P., Field, R. A., Flynn, J. H., Gilman, J. B., and Graus, M.: High winter ozone pollution from carbonyl photolysis in an oil and gas basin, Nature, 514, 351, https://doi.org/10.1038/nature13767, 2014.

EGR (Eastern Research Group): City of Fort Worth Natural Gas Air Quality Study, Morrisville, NC, 2011.

EIA (Energy Information Administration): Shale oil and shale gas resources are globally abundant, available at: https://www. eia.gov/todayinenergy/detail.php?id=14431 (last access: $13 \mathrm{Au}$ gust 2019), 2014.

EIA (Energy Information Administration): Production of Crude Oil including Lease Condensate 2016, available at: https://www. eia.gov/beta/international/data/browser/ (last access: $13 \mathrm{Au}$ gust 2019), 2017. 
EIA (Energy Information Administration): Annual Energy Outlook 2018: With Projections to 2050, available at: https://www. eia.gov/outlooks/aeo/pdf/AEO2018.pdf (last access: $13 \mathrm{Au}-$ gust 2019), 2018.

Elshorbany, Y. F., Kurtenbach, R., Wiesen, P., Lissi, E., Rubio, M., Villena, G., Gramsch, E., Rickard, A. R., Pilling, M. J., and Kleffmann, J.: Oxidation capacity of the city air of Santiago, Chile, Atmos. Chem. Phys., 9, 2257-2273, https://doi.org/10.5194/acp9-2257-2009, 2009.

Field, R. A., Soltis, J., and Murphy, S.: Air quality concerns of unconventional oil and natural gas production, Environ. Sci.-Proc Imp., 16, 954-969, https://doi.org/10.1039/c4em00081a, 2014.

Field, R. A., Soltis, J., McCarthy, M. C., Murphy, S., and Montague, D. C.: Influence of oil and gas field operations on spatial and temporal distributions of atmospheric non-methane hydrocarbons and their effect on ozone formation in winter, Atmos. Chem. Phys., 15, 3527-3542, https://doi.org/10.5194/acp15-3527-2015, 2015.

Geyer, A., Alicke, B., Konrad, S., Schmitz, T., Stutz, J., and Platt, U.: Chemistry and oxidation capacity of the nitrate radical in the continental boundary layer near Berlin, J. Geophys. Res.-Atmos., 106, 8013-8025, https://doi.org/10.1029/2000jd900681, 2001.

Gilman, J. B., Lerner, B. M., Kuster, W. C., and De Gouw, J.: Source signature of volatile organic compounds from oil and natural gas operations in northeastern Colorado, Environ. Sci. Technol., 47, 1297-1305, https://doi.org/10.1021/es304119a, 2013.

Helmig, D., Thompson, C., Evans, J., Boylan, P., Hueber, J., and Park, J.-H.: Highly elevated atmospheric levels of volatile organic compounds in the Uintah Basin, Utah, Environ. Sci. Technol., 48, 4707-4715, https://doi.org/10.1021/es405046r, 2014.

Kanaya, Y., Cao, R., Akimoto, H., Fukuda, M., Komazaki, Y., Yokouchi, Y., Koike, M., Tanimoto, H., Takegawa, N., and Kondo, Y.: Urban photochemistry in central Tokyo: 1. Observed and modeled $\mathrm{OH}$ and $\mathrm{HO}_{2}$ radical concentrations during the winter and summer of 2004, J. Geophys. Res.-Atmos., 112, D21312, https://doi.org/10.1029/2007jd008670, 2007.

Kemball-Cook, S., Bar-Ilan, A., Grant, J., Parker, L., Jung, J., Santamaria, W., Mathews, J., and Yarwood, G.: Ozone impacts of natural gas development in the Haynesville Shale, Environ. Sci. Technol., 44, 9357-9363, https://doi.org/10.1021/es1021137, 2010.

Koss, A. R., de Gouw, J., Warneke, C., Gilman, J. B., Lerner, B. M., Graus, M., Yuan, B., Edwards, P., Brown, S. S., Wild, R., Roberts, J. M., Bates, T. S., and Quinn, P. K.: Photochemical aging of volatile organic compounds associated with oil and natural gas extraction in the Uintah Basin, UT, during a wintertime ozone formation event, Atmos. Chem. Phys., 15, 5727-5741, https://doi.org/10.5194/acp-15-5727-2015, 2015.

Lee, L., Wooldridge, P. J., Gilman, J. B., Warneke, C., de Gouw, J., and Cohen, R. C.: Low temperatures enhance organic nitrate formation: evidence from observations in the 2012 Uintah Basin Winter Ozone Study, Atmos. Chem. Phys., 14, 12441-12454, https://doi.org/10.5194/acp-14-12441-2014, 2014.

Li, Z., Xue, L., Yang, X., Zha, Q., Tham, Y. J., Yan, C., Louie, P. K., Luk, C. W., Wang, T., and Wang, W.: Oxidizing capacity of the rural atmosphere in Hong Kong, Southern China, Sci. Total Environ., 612, 1114-1122, https://doi.org/10.1016/j.scitotenv.2017.08.310, 2018.

Lou, S., Holland, F., Rohrer, F., Lu, K., Bohn, B., Brauers, T., Chang, C. C., Fuchs, H., Häseler, R., Kita, K., Kondo, Y.,
Li, X., Shao, M., Zeng, L., Wahner, A., Zhang, Y., Wang, W., and Hofzumahaus, A.: Atmospheric $\mathrm{OH}$ reactivities in the Pearl River Delta - China in summer 2006: measurement and model results, Atmos. Chem. Phys., 10, 11243-11260, https://doi.org/10.5194/acp-10-11243-2010, 2010.

Lu, K. D., Rohrer, F., Holland, F., Fuchs, H., Bohn, B., Brauers, T., Chang, C. C., Häseler, R., Hu, M., Kita, K., Kondo, Y., Li, X., Lou, S. R., Nehr, S., Shao, M., Zeng, L. M., Wahner, A., Zhang, Y. H., and Hofzumahaus, A.: Observation and modelling of $\mathrm{OH}$ and $\mathrm{HO}_{2}$ concentrations in the Pearl River Delta 2006: a missing $\mathrm{OH}$ source in a VOC rich atmosphere, Atmos. Chem. Phys., 12, 1541-1569, https://doi.org/10.5194/acp-12-1541-2012, 2012.

Lu, K. D., Hofzumahaus, A., Holland, F., Bohn, B., Brauers, T., Fuchs, H., Hu, M., Häseler, R., Kita, K., Kondo, Y., Li, X., Lou, S. R., Oebel, A., Shao, M., Zeng, L. M., Wahner, A., Zhu, T., Zhang, Y. H., and Rohrer, F.: Missing OH source in a suburban environment near Beijing: observed and modelled $\mathrm{OH}$ and $\mathrm{HO}_{2}$ concentrations in summer 2006, Atmos. Chem. Phys., 13, 10571080, https://doi.org/10.5194/acp-13-1057-2013, 2013.

Lu, S., Bai, Y., and Zhang, G.: Study on the characteristics of VOCs source profiles of vehicle exhaust and gasoline emission, Acta Scicentiarum Naturalum Universitis Pekinesis, 39, 507511, 2003.

Ma, Z., Xu, J., Quan, W., Zhang, Z., Lin, W., and Xu, X.: Significant increase of surface ozone at a rural site, north of eastern China, Atmos. Chem. Phys., 16, 3969-3977, https://doi.org/10.5194/acp-16-3969-2016, 2016.

Mao, J., Ren, X., Chen, S., Brune, W. H., Chen, Z., Martinez, M., Harder, H., Lefer, B., Rappenglueck, B., Flynn, J., and Leuchner, M.: Atmospheric oxidation capacity in the summer of Houston 2006: Comparison with summer measurements in other metropolitan studies, Atmos. Environ., 44, 4107-4115, https://doi.org/10.1016/j.atmosenv.2009.01.013, 2010.

Martinez, M., Harder, H., Kovacs, T. A., Simpas, J. B., Bassis, J., Lesher, R., Brune, W. H., Frost, G. J., Williams, E. J., Stroud, C. A., and Jobson, B. T.: $\mathrm{OH}$ and $\mathrm{HO}_{2}$ concentrations, sources, and loss rates during the Southern Oxidants Study in Nashville, Tennessee, summer 1999, J. Geophys. Res.-Atmos., 108, 4617, https://doi.org/10.1029/2003jd003551, 2003.

McDuffie, E. E., Edwards, P. M., Gilman, J. B., Lerner, B. M., Dubé, W. P., Trainer, M., Wolfe, D. E., Angevine, W. M., deGouw, J., Williams, E. J., and Tevlin, A. G.: Influence of oil and gas emissions on summertime ozone in the Colorado Northern Front Range, J. Geophys. Res.-Atmos., 121, 8712-8729, https://doi.org/10.1002/2016jd025265, 2016.

McKenzie, L. M., Witter, R. Z., Newman, L. S., and Adgate, J. L.: Human health risk assessment of air emissions from development of unconventional natural gas resources, Sci. Total Environ., 424 79-87, https://doi.org/10.1016/j.scitotenv.2012.02.018, 2012.

National Research Council: Rethinking the ozone problem in urban and regional air pollution, National Academies Press, Washington, DC, https://doi.org/10.17226/1889, 1992.

Neemann, E. M., Crosman, E. T., Horel, J. D., and Avey, L.: Simulations of a cold-air pool associated with elevated wintertime ozone in the Uintah Basin, Utah, Atmos. Chem. Phys., 15, 135151, https://doi.org/10.5194/acp-15-135-2015, 2015.

Olaguer, E. P.: The potential near-source ozone impacts of upstream oil and gas industry emissions, J. Air Waste Manage., 62, 966977, https://doi.org/10.1080/10962247.2012.688923, 2012. 
Ren, X., Brune, W. H., Mao, J., Mitchell, M. J., Lesher, R. L., Simpas, J. B., Metcalf, A. R., Schwab, J. J., Cai, C., Li, Y., and Demerjian, K. L.: $\mathrm{OH}, \mathrm{HO}_{2}$, and $\mathrm{OH}$ reactivity during the PMTACS-NY Whiteface Mountain 2002 campaign: Observations and model comparison, J. Geophys. Res.-Atmos., 111, D10S03, https://doi.org/10.1029/2005jd006126, 2006.

Rodriguez, M. A., Barna, M. G., and Moore, T.: Regional impacts of oil and gas development on ozone formation in the western United States, J. Air Waste Manage., 59, 1111-1118, https://doi.org/10.3155/1047-3289.59.9.1111, 2009.

Rohrer, F. and Berresheim, H.: Strong correlation between levels of tropospheric hydroxyl radicals and solar ultraviolet radiation, Nature, 442, 184, https://doi.org/10.1038/nature04924, 2006.

Rutter, A. P., Griffin, R. J., Cevik, B. K., Shakya, K. M., Gong, L., Kim, S., Flynn, J. H., and Lefer, B. L.: Sources of air pollution in a region of oil and gas exploration downwind of a large city, Atmos. Environ., 120, 89-99, https://doi.org/10.1016/j.atmosenv.2015.08.073, 2015.

Saunders, S. M., Jenkin, M. E., Derwent, R. G., and Pilling, M. J.: Protocol for the development of the Master Chemical Mechanism, MCM v3 (Part A): tropospheric degradation of nonaromatic volatile organic compounds, Atmos. Chem. Phys., 3, 161-180, https://doi.org/10.5194/acp-3-161-2003, 2003.

Schnell, R. C., Oltmans, S. J., Neely, R. R., Endres, M. S., Molenar, J. V., and White, A. B.: Rapid photochemical production of ozone at high concentrations in a rural site during winter, Nat. Geosci., 2, 120, https://doi.org/10.1038/ngeo415, 2009.

Seo, S.: A review and comparison of methods for detecting outliers in univariate data sets, University of Pittsburgh, available at: http: //d-scholarship.pitt.edu/7948/ (last access: 4 June 2020), 2006.

Shao, P., An, J., Xin, J., Wu, F., Wang, J., Ji, D., and Wang, Y.: Source apportionment of VOCs and the contribution to photochemical ozone formation during summer in the typical industrial area in the Yangtze River Delta, China, Atmos. Res., 176, 64-74, https://doi.org/10.1016/j.atmosres.2016.02.015, 2016.

Simpson, I. J., Blake, N. J., Barletta, B., Diskin, G. S., Fuelberg, H. E., Gorham, K., Huey, L. G., Meinardi, S., Rowland, F. S., Vay, S. A., Weinheimer, A. J., Yang, M., and Blake, D. R.: Characterization of trace gases measured over Alberta oil sands mining operations: 76 speciated $\mathrm{C}_{2}-\mathrm{C}_{10}$ volatile organic compounds (VOCs), $\mathrm{CO}_{2}, \mathrm{CH}_{4}, \mathrm{CO}, \mathrm{NO}, \mathrm{NO}_{2}, \mathrm{NO}_{y}, \mathrm{O}_{3}$ and $\mathrm{SO}_{2}$, Atmos. Chem. Phys., 10, 11931-11954, https://doi.org/10.5194/acp-1011931-2010, 2010.

Smith, S. C., Lee, J. D., Bloss, W. J., Johnson, G. P., Ingham, T., and Heard, D. E.: Concentrations of $\mathrm{OH}$ and $\mathrm{HO}_{2}$ radicals during NAMBLEX: measurements and steady state analysis, Atmos. Chem. Phys., 6, 1435-1453, https://doi.org/10.5194/acp-6-14352006, 2006.

Statista: Leading countries based on natural gas production in 2016 (in billion cubic meters), available at: https://www.statista.com/statistics/264771/ top-countries-based-on-natural-gas-production/ (last access: last access: 4 June 2020), 2018.

Sun, J., Li, Z., Xue, L., Wang, T., Wang, X., Gao, J., Nie, W., Simpson, I. J., Gao, R., Blake, D. R., and Chai, F.: Summertime $\mathrm{C}_{1}-\mathrm{C}_{5}$ alkyl nitrates over Beijing, northern China: Spatial distribution, regional transport, and formation mechanisms, Atmos. Res., 204, 102-109, https://doi.org/10.1016/j.atmosres.2018.01.014, 2018.
Sun, L., Xue, L., Wang, T., Gao, J., Ding, A., Cooper, O. R., Lin, M., Xu, P., Wang, Z., Wang, X., Wen, L., Zhu, Y., Chen, T., Yang, L., Wang, Y., Chen, J., and Wang, W.: Significant increase of summertime ozone at Mount Tai in Central Eastern China, Atmos. Chem. Phys., 16, 10637-10650, https://doi.org/10.5194/acp-1610637-2016, 2016.

Tan, Z., Fuchs, H., Lu, K., Hofzumahaus, A., Bohn, B., Broch, S., Dong, H., Gomm, S., Häseler, R., He, L., Holland, F., Li, X., Liu, Y., Lu, S., Rohrer, F., Shao, M., Wang, B., Wang, M., Wu, Y., Zeng, L., Zhang, Y., Wahner, A., and Zhang, Y.: Radical chemistry at a rural site (Wangdu) in the North China Plain: observation and model calculations of $\mathrm{OH}, \mathrm{HO}_{2}$ and $\mathrm{RO}_{2}$ radicals, Atmos. Chem. Phys., 17, 663-690, https://doi.org/10.5194/acp17-663-2017, 2017.

Tan, Z., Lu, K., Hofzumahaus, A., Fuchs, H., Bohn, B., Holland, F., Liu, Y., Rohrer, F., Shao, M., Sun, K., Wu, Y., Zeng, L., Zhang, Y., Zou, Q., Kiendler-Scharr, A., Wahner, A., and Zhang, Y.: Experimental budgets of $\mathrm{OH}, \mathrm{HO} 2$, and $\mathrm{RO} 2$ radicals and implications for ozone formation in the Pearl River Delta in China 2014, Atmos. Chem. Phys., 19, 7129-7150, https://doi.org/10.5194/acp-19-7129-2019, 2019a.

Tan, Z., Lu, K., Jiang, M., Su, R., Wang, H., Lou, S., Fu, Q., Zhai, C., Tan, Q., Yue, D., Chen, D., Wang, Z., Xie, S., Zeng, L., and Zhang, Y.: Daytime atmospheric oxidation capacity in four Chinese megacities during the photochemically polluted season: a case study based on box model simulation, Atmos. Chem. Phys., 19, 3493-3513, https://doi.org/10.5194/acp-193493-2019, 2019b.

Vinciguerra, T., Yao, S., Dadzie, J., Chittams, A., Deskins, T., Ehrman, S., and Dickerson, R. R.: Regional air quality impacts of hydraulic fracturing and shale natural gas activity: Evidence from ambient VOC observations, Atmos. Environ., 110, 144 150, https://doi.org/10.1016/j.atmosenv.2015.03.056, 2015.

Wang, T., Wei, X. L., Ding, A. J., Poon, C. N., Lam, K. S., Li, Y. S., Chan, L. Y., and Anson, M.: Increasing surface ozone concentrations in the background atmosphere of Southern China, 1994-2007, Atmos. Chem. Phys., 9, 6217-6227, https://doi.org/10.5194/acp-9-6217-2009, 2009.

Wang, T., Xue, L., Brimblecombe, P., Lam, Y. F., Li, L., and Zhang, L.: Ozone pollution in China: A review of concentrations, meteorological influences, chemical precursors, and effects, Sci. Total Environ., 575, 1582-1596, https://doi.org/10.1016/j.scitotenv.2016.10.081, 2017.

Warneke, C., Geiger, F., Edwards, P. M., Dube, W., Pétron, G., Kofler, J., Zahn, A., Brown, S. S., Graus, M., Gilman, J. B., Lerner, B. M., Peischl, J., Ryerson, T. B., de Gouw, J. A., and Roberts, J. M.: Volatile organic compound emissions from the oil and natural gas industry in the Uintah Basin, Utah: oil and gas well pad emissions compared to ambient air composition, Atmos. Chem. Phys., 14, 10977-10988, https://doi.org/10.5194/acp-1410977-2014, 2014.

Williams, J., Kessel, S. U., Nolscher, A. C., Yang, Y. D., Lee, Y., Yanez-Serrano, A. M., Wolff, S., Kesselmeier, J., Klupfel, T., Lelieveld, J., and Shao, M.: Opposite OH reactivity and ozone cycles in the Amazon rainforest and megacity Beijing: Subversion of biospheric oxidant control by anthropogenic emissions, Atmos. Environ., 125, 112-118, https://doi.org/10.1016/j.atmosenv.2015.11.007, 2016. 
Xu, W., Xu, X., Lin, M., Lin, W., Tarasick, D., Tang, J., Ma, J., and Zheng, X.: Long-term trends of surface ozone and its influencing factors at the Mt Waliguan GAW station, China - Part 2: The roles of anthropogenic emissions and climate variability, Atmos. Chem. Phys., 18, 773-798, https://doi.org/10.5194/acp-18-7732018, 2018.

Xu, X., Lin, W., Wang, T., Yan, P., Tang, J., Meng, Z., and Wang, Y.: Long-term trend of surface ozone at a regional background station in eastern China 1991-2006: enhanced variability, Atmos. Chem. Phys., 8, 2595-2607, https://doi.org/10.5194/acp-8-25952008, 2008.

Xue, L., Wang, T., Louie, P. K., Luk, C. W., Blake, D. R., and Xu, Z.: Increasing external effects negate local efforts to control ozone air pollution: a case study of Hong Kong and implications for other Chinese cities, Environ. Sci. Technol., 48, 10769-10775, https://doi.org/10.1021/es503278g, 2014.

Xue, L., Gu, R., Wang, T., Wang, X., Saunders, S., Blake, D., Louie, P. K. K., Luk, C. W. Y., Simpson, I., Xu, Z., Wang, Z., Gao, Y., Lee, S., Mellouki, A., and Wang, W.: Oxidative capacity and radical chemistry in the polluted atmosphere of Hong Kong and Pearl River Delta region: analysis of a severe photochemical smog episode, Atmos. Chem. Phys., 16, 9891-9903, https://doi.org/10.5194/acp-16-9891-2016, 2016.

Xue, L. K., Wang, T., Guo, H., Blake, D. R., Tang, J., Zhang, X. C., Saunders, S. M., and Wang, W. X.: Sources and photochemistry of volatile organic compounds in the remote atmosphere of western China: results from the Mt. Waliguan Observatory, Atmos. Chem. Phys., 13, 8551-8567, https://doi.org/10.5194/acp13-8551-2013, 2013.

Xue, L. K., Wang, T., Gao, J., Ding, A. J., Zhou, X. H., Blake, D. R., Wang, X. F., Saunders, S. M., Fan, S. J., Zuo, H. C., Zhang, Q. Z., and Wang, W. X.: Ground-level ozone in four Chinese cities: precursors, regional transport and heterogeneous processes, Atmos. Chem. Phys., 14, 13175-13188, https://doi.org/10.5194/acp-1413175-2014, 2014.

Xue, L. K., Saunders, S. M., Wang, T., Gao, R., Wang, X. F., Zhang, Q. Z., and Wang, W. X.: Development of a chlorine chemistry module for the Master Chemical Mechanism, Geosci. Model Dev., 8, 3151-3162, https://doi.org/10.5194/gmd-8-3151-2015, 2015.
Yang, X., Xue, L., Wang, T., Wang, X., Gao, J., Lee, S., Blake, D. R., Chai, F., and Wang, W.: Observations and explicit modeling of summertime carbonyl formation in Beijing: Identification of key precursor species and their impact on atmospheric oxidation chemistry, J. Geophys. Res.-Atmos., 123, 1426-1440, https://doi.org/10.1002/2017JD027403, 2018.

Yang, Y., Shao, M., Keßel, S., Li, Y., Lu, K., Lu, S., Williams, J., Zhang, Y., Zeng, L., Nölscher, A. C., Wu, Y., Wang, X., and Zheng, J.: How the $\mathrm{OH}$ reactivity affects the ozone production efficiency: case studies in Beijing and Heshan, China, Atmos. Chem. Phys., 17, 7127-7142, https://doi.org/10.5194/acp17-7127-2017, 2017.

Yuan, B., Shao, M., de Gouw, J., Parrish, D.D., Lu, S., Wang, M., Zeng, L., Zhang, Q., Song, Y., Zhang, J., and Hu, M.: Volatile organic compounds (VOCs) in urban air: How chemistry affects the interpretation of positive matrix factorization (PMF) analysis, J. Geophys. Res.-Atmos., 117, D24302, https://doi.org/10.1029/2012JD018236, 2012.

Zhang, Y., Sun, J., Zheng, P., Chen, T., Liu, Y., Han, G., Simpson, I. J., Wang, X., Blake, D. R., Li, Z., and Yang, X.: Observations of $\mathrm{C}_{1}-\mathrm{C}_{5}$ alkyl nitrates in the Yellow River Delta, northern China: Effects of biomass burning and oil field emissions, Sci. Total Environ., 656, 129-139, https://doi.org/10.1016/j.scitotenv.2018.11.208, 2019.

Zhang, Y. H., Su, H., Zhong, L. J., Cheng, Y. F., Zeng, L. M., Wang, X. S., Xiang, Y. R., Wang, J. L., Gao, D. F., Shao, M., and Fan, S. J.: Regional ozone pollution and observation-based approach for analyzing ozone-precursor relationship during the PRIDE-PRD2004 campaign, Atmos. Environ., 42, 6203-6218, https://doi.org/10.1016/j.atmosenv.2008.05.002, 2008.

Zhao, N., Zhang, Q., and Wang, W.: Atmospheric oxidation of phenanthrene initiated by $\mathrm{OH}$ radicals in the presence of $\mathrm{O}_{2}$ and $\mathrm{NO}_{x}$ - A theoretical study, Sci. Total Environ., 563, 1008-1015, https://doi.org/10.1016/j.scitotenv.2016.01.089, 2016. 